\title{
Phytoplankton growth response to Asian dust addition in the northwest Pacific Ocean versus the Yellow Sea
}

\author{
Chao Zhang ${ }^{1}$, Huiwang Gao ${ }^{1,2}$, Xiaohong Yao ${ }^{1}$, Zongbo Shi ${ }^{3}$, Jinhui Shi ${ }^{1}$, Yang Yu$^{1}$, Ling Meng ${ }^{1}$, and Xinyu Guo ${ }^{4}$ \\ ${ }^{1}$ Key Laboratory of Marine Environment and Ecology, Ministry of Education of China, Ocean University of China, \\ Qingdao, China \\ ${ }^{2}$ Laboratory for Marine Ecology and Environmental Sciences, Qingdao National Laboratory for Marine Science and \\ Technology, Qingdao 266071, China \\ ${ }^{3}$ School of Geography, Earth and Environmental Sciences, University of Birmingham, Birmingham, UK \\ ${ }^{4}$ Center for Marine Environmental Studies, Ehime University, Matsuyama, Japan
}

Correspondence: Huiwang Gao (hwgao@ouc.edu.cn)

Received: 5 May 2017 - Discussion started: 30 June 2017

Revised: 26 December 2017 - Accepted: 5 January 2018 - Published: 7 February 2018

\begin{abstract}
In this study, five on-board microcosm experiments were performed in the subtropical gyre, the Kuroshio Extension region of the northwest Pacific Ocean (NWPO), and the Yellow Sea (YS) in order to investigate phytoplankton growth following the addition of artificially modified mineral dust (AM dust) and various nutrients (nitrogen $(\mathrm{N})$, phosphorus $(\mathrm{P})$, iron $(\mathrm{Fe}), \mathrm{N}+\mathrm{P}$, and $\mathrm{N}+\mathrm{P}+\mathrm{Fe})$. The two experiments carried out with AM-dust addition in the subtropical gyre showed a maximum chlorophyll $a(\mathrm{Chl} a)$ concentration increase of 1.7- and 2.8-fold, while the cell abundance of large-sized phytoplankton $(>5 \mu \mathrm{m})$ showed a 1.8and 3.9-fold increase, respectively, relative to the controls. However, in the Kuroshio Extension region and the YS, the increases in maximum Chl $a$ and cell abundance of largesized phytoplankton following AM-dust addition were at most 1.3-fold and 1.7-fold larger than those in the controls, respectively. A net conversion efficiency index (NCEI) newly proposed in this study, size-fractionated $\mathrm{Chl} a$, and the abundance of large-sized phytoplankton were analysed to determine which nutrients contribute to supporting phytoplankton growth. Our results demonstrate that a combination of nutrients, $\mathrm{N}-\mathrm{P}$ or $\mathrm{N}+\mathrm{P}+\mathrm{Fe}$, is responsible for phytoplankton growth in the subtropical gyre following AM-dust addition. Single nutrient addition, i.e., $\mathrm{N}$ in the Kuroshio Extension region and $\mathrm{P}$ or $\mathrm{N}$ in the $\mathrm{YS}$, controls the phytoplankton growth following AM-dust addition. In the AM-dust-addition experiments, in which the increased $\mathrm{N}-\mathrm{P}$ or $\mathrm{P}$ was identified to determine phytoplankton growth, the dissolved inorganic $\mathrm{P}$
\end{abstract}

from AM dust $\left(8.6 \mathrm{nmol} \mathrm{L}^{-1}\right)$ was much lower than the theoretically estimated minimum $\mathrm{P}$ demand $\left(\sim 20 \mathrm{nmol} \mathrm{L}^{-1}\right)$ for phytoplankton growth. These observations suggest that additional supply augments the bioavailable $\mathrm{P}$ stock in incubated seawater with AM-dust addition, most likely due to an enhanced solubility of $\mathrm{P}$ from AM dust or the remineralization of the dissolved organic P.

\section{Introduction}

Aeolian dust deposition can supply bioavailable nutrients such as nitrogen $(\mathrm{N})$, phosphorus $(\mathrm{P})$, and iron $(\mathrm{Fe})$ to the upper ocean layers (Duce et al., 1991; Jickells et al., 2005; Kanakidou et al., 2012). Observational and modelling studies have demonstrated that external nutrient input can stimulate primary productivity, strengthen nitrogen fixation, alter phytoplankton size, and potentially enhance carbon sequestration by the biological pump in the ocean (Mills et al., 2004; Maranon et al., 2010; Liu et al., 2013). A wellrecognized aspect of dust deposition is the iron fertilization effect in high-nutrient low-chlorophyll (HNLC) regions (Martin, 1991; Boyd et al., 2007). Recently, many studies have attempted to explore the primary chemicals that promote phytoplankton growth following dust deposition in low-nutrient low-chlorophyll (LNLC) regions, which cover $\sim 60 \%$ of the ocean area worldwide (Moore et al., 2008; C. Guo et al., 2012; Ridame et al., 2014; Li et al., 2015). 
For example, dissolved $\mathrm{Fe}$ and $\mathrm{P}$ from deposited dust were reported to stimulate nitrogen fixation in the oligotrophic region of the eastern tropical North Atlantic Ocean (Mills et al., 2004). In the oligotrophic region of the western North Atlantic Ocean off Barbados, a greater concentration of dissolved $\mathrm{N}$ and $\mathrm{Fe}$ relative to $\mathrm{P}$, arising from the deposited dust, likely favoured the growth of Prochlorococcus, but limited the activity of diazotrophs (Chien et al., 2016). Moreover, the reported positive effect of dust deposition on primary production in the central Atlantic Ocean decreased with increasing oligotrophy of the seawater (Maranon et al., 2010). However, studies in areas other than the North Atlantic Ocean and the Mediterranean Sea are scarce.

Dust particles frequently mix with anthropogenic aerosols on their transport pathway to the oceans (Guieu et al., 2010; Shi et al., 2012; Herut et al., 2016). The response of phytoplankton to the added dust particles mixed with anthropogenic aerosols appeared to be more sensitive in oligotrophic waters than in moderately nutrient-enriched waters (C. Guo et al., 2012). Unlike in HNLC and LNLC regions of the oceans, the response of phytoplankton to dust deposition in coastal seas that receive a relatively large quantity of nutrients from rivers is poorly understood. A few studies showed that dissolved $\mathrm{N}$ from the added dust likely stimulated phytoplankton growth in the Yellow Sea (YS; Liu et al., 2013). Added Fe instead of other dissolved nutrients from atmospheric deposition played an important role in stimulating phytoplankton growth in the East China Sea (Meng et al., 2016). The complex responses of phytoplankton growth to dust deposition are worthy of investigation.

The $\mathrm{N}$ : $\mathrm{P}$ ratio of dust deposition is much higher than the Redfield ratio (N:P = 16; Baker et al., 2003; C. Guo et al., 2012), which reflects the average cellular N : P stoichiometry for oceanic phytoplankton (Arrigo, 2005). Although the deposited $\mathrm{P}$ was deficient relative to the demands of the resident phytoplankton in the ocean surface, a few studies showed that the input of dust could compensate for P deficiency to some extent by stimulating the biogenic conversion of dissolved organic P (DOP) to dissolved inorganic P (DIP) or a slow release of DIP from dust (Ridame and Guieu, 2002; Mackey et al., 2012; Krom et al., 2016). This supply of bioavailable P seemingly varies substantially across different oceanic regions and is affected by many factors, including dust sources and its mixing with anthropogenic pollutants, $\mathrm{P}$ demand, and the uptake of nutrients that are co-limiting for phytoplankton in the seawater (Mackey et al., 2012). It remains a challenge to accurately estimate the supply of bioavailable $\mathrm{P}$ for phytoplankton growth induced by dust deposition in specific environments.

The arid regions of eastern Asia are the most important mineral dust source to the western Pacific Ocean (Shao et al., 2011). In spring, strong westerly winds can carry large amounts of mineral dust from the Asian continent along a corridor between 25 and $45^{\circ} \mathrm{N}$ and bring significant amounts of nutrients to downwind areas, including the coastal seas of
China and Japan and the northwest Pacific Ocean (NWPO; Shao et al., 2011). During this long-range transport, the contents of bioavailable nutrients in the Asian dust might increase through mixing with air pollutants such as sulfur dioxide and nitrogen oxides (Formenti et al., 2011). The subtropical gyre in the NWPO is an LNLC region with $\mathrm{NO}_{3}^{-}+\mathrm{NO}_{2}^{-}$ and $\mathrm{PO}_{4}^{3-}$ concentrations generally maintained at nanomolar levels (Hashihama et al., 2009). Seawater in the Kuroshio Extension region, however, shows flexible characteristics in nutrients, which is ascribed to the confluence of the Oyashio current with replete nutrient stocks and that of the Kuroshio current with impoverished nutrient stocks (Measures et al., 2006; Kitajima et al., 2009). On the other hand, the YS is a semi-enclosed continental shelf region, which is located on the margin of the NWPO surrounded by the Chinese mainland and the Korean Peninsula. Seawater in the YS exhibits high nutrient levels but varying nutrient-limiting conditions, for example $\mathrm{N}$ or $\mathrm{P}$ limitation (Liu et al., 2003). Thus, the NWPO and YS are the ideal zones to explore how Asian dust deposition influences phytoplankton growth and community size shifts under varying nutrient levels in seawaters.

In this study, we conducted on-board bioassay incubations using artificially modified mineral dust (AM dust) collected from the Gobi Desert of China and native phytoplankton assemblages collected from the NWPO and YS to investigate the effect of atmospheric nutrients and trace metal inputs on phytoplankton growth. The measured concentrations of $\mathrm{Chl} a$ in the nutrient treatments (i.e., $\mathrm{N}, \mathrm{P}, \mathrm{Fe}, \mathrm{N}+\mathrm{P}$, and $\mathrm{N}+\mathrm{P}+\mathrm{Fe}$ additions) against the control were used to determine the nutrient limitation in the subtropical gyre, the Kuroshio Extension region of the NWPO, and the YS, respectively. The concentrations of total and size-fractionated Chl $a$ and the abundances and community structures of largesized phytoplankton $(>5 \mu \mathrm{m})$ were determined to study the responses of different-sized phytoplankton to the nutrients supplied by AM dust. A net conversion efficiency index (NCEI) is proposed to identify the key nutrient(s) in determining the increase in $\mathrm{Chl} a$ concentrations following AMdust addition at different incubation stations. Finally, we analysed the minimum P consumption that supports phytoplankton growth following AM-dust addition to estimate the $\mathrm{P}$ budget of the added dust.

\section{Materials and methods}

\subsection{Preparation of AM dust}

We collected surface soil samples $\left(42.37^{\circ} \mathrm{N}, 112.97^{\circ} \mathrm{E}\right)$ from the Gobi Desert, one of the most important sources of dust events crossing over the YS and NWPO (Ooki and Uematsu, 2005; Shao et al., 2011). The soil samples were crushed, sieved to less than $20 \mu \mathrm{m}$ particle size, and freeze-dried (Shi et al., 2009). To account for the ageing of dust particles in the atmosphere, we followed Guieu et al. (2010) by mixing 
Table 1. Experimental information and baseline conditions at the sampling stations.

\begin{tabular}{|c|c|c|c|c|c|}
\hline & Ar4 (S1) & (G7) S2 & $\mathrm{K} 4(\mathrm{~S} 3)$ & B7 (S4) & $\mathrm{H} 10$ (S5) \\
\hline Sampling date & 2014.3 .23 & 2014.4 .5 & 2014.4.14 & 2014.5 .9 & 2014.4.29 \\
\hline Incubation time & 10 days & 9 days & 9 days & 10 days & 9 days \\
\hline Sampling location & $29.5^{\circ} \mathrm{N}, 142.5^{\circ} \mathrm{E}$ & $30.0^{\circ} \mathrm{N}, 148.5^{\circ} \mathrm{E}$ & $34.0^{\circ} \mathrm{N}, 144.0^{\circ} \mathrm{E}$ & $37.0^{\circ} \mathrm{N}, 123.2^{\circ} \mathrm{E}$ & $35.0^{\circ} \mathrm{N}, 124.0^{\circ} \mathrm{E}$ \\
\hline $\begin{array}{l}\text { Sea surface temperature } \\
\left(\mathrm{SST},{ }^{\circ} \mathrm{C}\right)\end{array}$ & 18.9 & 18.3 & 18.6 & 9.8 & 12.6 \\
\hline $\begin{array}{l}\text { Mixed layer depth } \\
(\mathrm{MLD}, \mathrm{m})\end{array}$ & 150 & 82 & 103 & - & 18 \\
\hline Chl $a\left(\mu \mathrm{g} \mathrm{L}^{-1}\right)$ & 0.24 & 0.50 & 1.28 & 1.58 & 2.74 \\
\hline $\mathrm{NO}_{3}^{-}+\mathrm{NO}_{2}^{-}\left(\mu \mathrm{mol} \mathrm{L}^{-1}\right)$ & 0.26 & 0.04 & 0.51 & 3.20 & 0.28 \\
\hline $\mathrm{PO}_{4}^{3-}(\mu \mathrm{mol} \mathrm{L}-1)$ & 0.05 & 0.05 & 0.10 & 0.10 & 0.04 \\
\hline $\mathrm{N}: \mathrm{P}(\mu \mathrm{mol}: \mu \mathrm{mol})$ & 5 & $<1$ & 5 & 32 & 7 \\
\hline Micro-sized Chl $a(\%)$ & 6 & 8 & 28 & 14 & 27 \\
\hline Nano-sized Chl $a(\%)$ & 18 & 19 & 23 & 36 & 37 \\
\hline Pico-sized Chl $a(\%)$ & 76 & 73 & 49 & 50 & 36 \\
\hline $\begin{array}{l}\text { Large-sized phytoplankton } \\
\text { abundance (cell } \mathrm{mL}^{-1} \text { ) }\end{array}$ & 17 & 10 & 79 & 35 & 314 \\
\hline Diatoms (cell $\mathrm{mL}^{-1}$ ) & 12 & 6 & 74 & 16 & 286 \\
\hline Dinoflagellates (cell $\mathrm{mL}^{-1}$ ) & 5 & 4 & 5 & 19 & 28 \\
\hline
\end{tabular}

the soil with synthetic cloud water in a cleaned polypropylene bottle, then spread the solution on a polystyrene tray and evaporated the aqueous phase under clean air flow in a fume hood. A more detailed modification protocol is presented in the Supplement (Text S1 and Table S1). These treated soil dust particles are referred to as "AM dust". Clean plastic or plastic-coated materials were used for the preparation of AM dust to avoid metal contamination.

\subsection{Experimental design}

Five AM-dust-addition bioassay experiments were carried out on-board the R/V Dongfanghong II during two cruises in 2014 at stations Ar4, G7, and K4 in the NWPO (Cruise I: March-April) and B7 and H10 in the YS (Cruise II: AprilMay; Fig. 1 and Table 1). Based on the baseline Chl $a$ concentrations (Table 1), the five stations were redefined as $\mathrm{S} 1$ (Ar4), S2 (G7), S3 (K4), S4 (B7), and S5 (H10) in ascending order. Surface seawater $(2-5 \mathrm{~m})$ was collected using acid-washed Teflon-coated Go-Flo bottles mounted on a SeaBird CTD assembly (SBE 911, USA) and filtered through a $200 \mu \mathrm{m}$ acid-washed mesh to remove larger grazers. Filtered seawater with different additions (true replicates, detailed in Table 2) was randomly dispensed into 18 pre-acidwashed and sample-rinsed (three times) Nalgene polycarbonate bottles $(20 \mathrm{~L}$ each). Water samples in the incubated bottles were collected before the additions to characterize the baseline seawater samples and immediately after the additions to characterize the amended seawater (day 0). Surface seawater was pumped into the microcosm equipment, i.e., three large plastic vessels, to stabilize the temperature of the incubation systems (Liu et al., 2013). The incubation exper- iments were processed over 9-10 days under natural light. Water samples were collected from incubated bottles at 08:00 every day except day 1 (i.e., day 2 through day 9-10) to determine $\mathrm{Chl} a$ and nutrient concentrations and on certain days for phytoplankton identification and enumeration.

Treatments included AM-dust and single nutrient (N, P, or $\mathrm{Fe}$ ) additions as well as $\mathrm{N}+\mathrm{P}$ and $\mathrm{N}+\mathrm{P}+\mathrm{Fe}$ (Table 2). Previous studies showed that the annual deposition flux of Asian dust in the YS and NWPO regions ranged from 10 to $80 \mathrm{~g} \mathrm{~m}^{-2} \mathrm{yr}^{-1}$ (Gao et al., 1992; Brown et al., 2005). An extreme dust storm event accompanied by wet precipitation in the YS can lead to a considerable dust deposition flux in this range (Shi et al., 2012). Considering these results, we added $2 \mathrm{mg} \mathrm{L}^{-1}$ of the AM dust to the incubated seawater to simulate deposition due to a strong dust event $\left(20 \mathrm{~g} \mathrm{~m}^{-2}\right)$ in the upper $10 \mathrm{~m}$ water layer in the YS (Liu et al., 2013). We added the same amount of AM dust for incubation experiments in the NWPO for comparison. This amount of added dust has been widely used in other studies as well (Mills et al., 2004; Maranon et al., 2010). Based on the N-deposition flux in the NWPO (Kim et al., 2014) and an estimate of the $\mathrm{N}$ addition by a dust event in the surface water of the YS (Shi et al., 2012), we added $40 \mu \mathrm{mol} \mathrm{NaNO} 3$ into the $20 \mathrm{~L}$ bottles for the $\mathrm{N}$-related treatments $(\mathrm{N}, \mathrm{N}+\mathrm{P}$, and $\mathrm{N}+\mathrm{P}+\mathrm{Fe}$ additions $)$ to increase the $\mathrm{N}$ concentration by $2 \mu \mathrm{mol} \mathrm{L}{ }^{-1}$. The added $\mathrm{P}$ and $\mathrm{Fe}$ amounts in the incubation systems were $0.2 \mu \mathrm{mol} \mathrm{L}-1$ and $2 \mathrm{nmol} \mathrm{L}^{-1}$, respectively, based on the nutrient-addition experiments conducted in the NWPO and YS (Noiri et al., 2005; Liu et al., 2013; Table 2).

One-way analysis of variance (ANOVA) was used to assess significant differences in the mean values of the selected parameters among various treatments, and then Dunnett's 
Table 2. Treatments to the bioassay incubation experiments.

\begin{tabular}{|c|c|c|}
\hline Incubation no. & Treatments & Amended concentrations \\
\hline 1 & Control & - \\
\hline 2 & AM dust & $2 \mathrm{mg} \mathrm{L}^{-1}$ \\
\hline 3 & $\mathrm{NaNO}_{3}$ & $2 \mu \mathrm{mol} \mathrm{L}-1$ \\
\hline 4 & $\mathrm{NaH}_{2} \mathrm{PO}_{4}$ & $0.2 \mu \mathrm{mol} \mathrm{L}^{-1}$ \\
\hline $5^{*}$ & $\mathrm{FeCl}_{3}$ & $2 \mathrm{nmol} \mathrm{L}^{-1}$ \\
\hline 6 & $\mathrm{NaNO}_{3}+\mathrm{NaH}_{2} \mathrm{PO}_{4}$ & 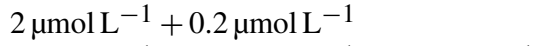 \\
\hline 7 & $\mathrm{NaNO}_{3}+\mathrm{NaH}_{2} \mathrm{PO}_{4}+\mathrm{FeCl}_{3}$ & $2 \mu \mathrm{mol} \mathrm{L}-1+0.2 \mu \mathrm{mol} \mathrm{L}^{-1}+2 \mathrm{nmol} \mathrm{L}^{-1}$ \\
\hline
\end{tabular}

* Only at stations S2 and S4.

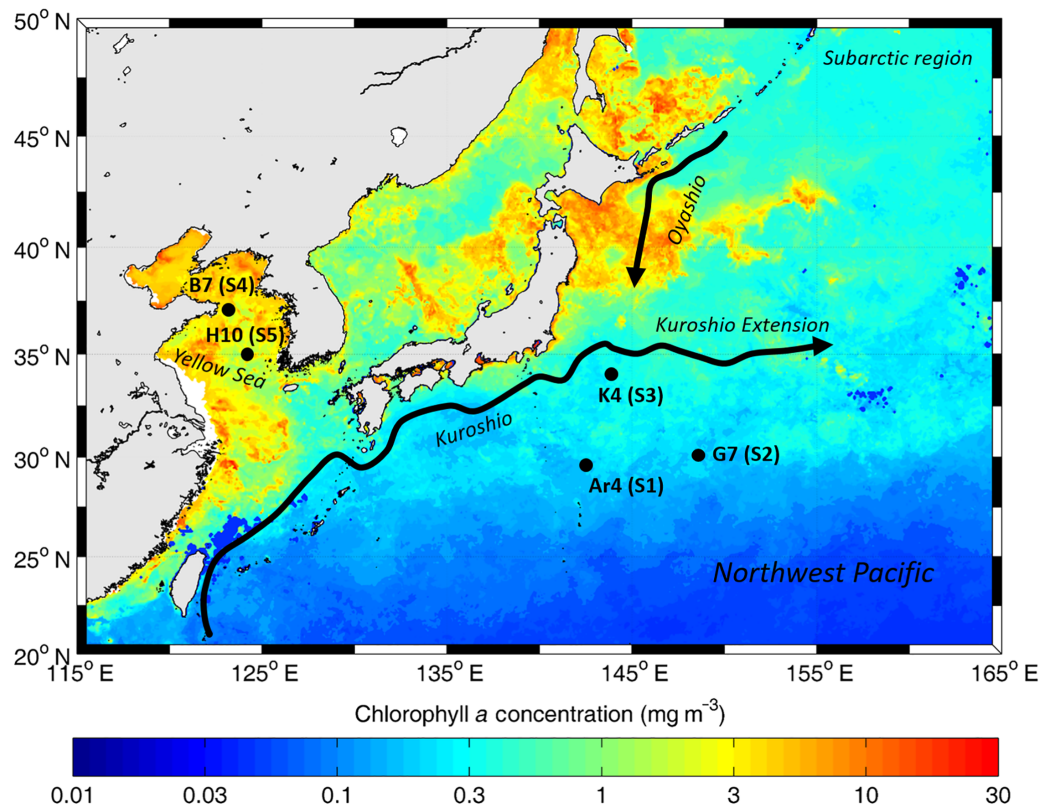

Figure 1. Locations of the five seawater collection stations for the microcosm experiments (the base map reflects an average composite of Chl $a$ concentrations in March-May 2014 obtained from the NASA website at https://modis.gsfc.nasa.gov/data/dataprod/chlor_a.php).

test was used to compare these treatments with the control using SPSS (Statistical Product and Service Solutions) software.

\subsection{Chl $a$ concentration}

From each bottle, a $300 \mathrm{~mL}$ seawater sample was sequentially filtered through 20,2 , and $0.2 \mu \mathrm{m}$ Whatman polycarbonate filters to determine size-fractionated $\mathrm{Chl} a$ concentrations, i.e., pico-sized $(0.2-2 \mu \mathrm{m})$, nano-sized $(2-20 \mu \mathrm{m})$, and micro-sized $(>20 \mu \mathrm{m}) \mathrm{Chl} a$. The pigments on the filters were extracted in $90 \%$ acetone at $-20^{\circ} \mathrm{C}$ over $24 \mathrm{~h}$ in the dark and measured on a Turner Designs Trilogy fluorometer (Strickland and Parsons, 1972). The total Chl $a$ concentration was calculated as the sum of the three size-fractionated values.

\subsection{Inorganic nutrients and trace metals}

To determine the soluble nutrients such as $\mathrm{NO}_{3}^{-}, \mathrm{NO}_{2}^{-}, \mathrm{NH}_{4}^{+}$, and $\mathrm{PO}_{4}^{3-}$ leached from $\mathrm{AM}$ dust, oligotrophic seawater was pre-filtered by $0.2 \mu \mathrm{m}$ glass fibre filters and used for extracting these ions at $\sim 0^{\circ}$ for $30 \mathrm{~min}$ in an ultrasonic bath filled with ice and water. A $200 \mathrm{~mL}$ seawater sample retrieved from each of the incubation bottles was filtered through preacid-washed cellulose acetate membranes and filtrates were stored immediately at $-20^{\circ} \mathrm{C}$ in acid-washed high-density polyethylene bottles for nutrient analysis in the laboratory. Soluble nutrients leached from AM dust and in the incubated seawaters were measured following the automated colorimetric technique described by Grasshoff et al. (1999) and Ridame et al. (2014) using a QuAAtro continuous-flow analyser (SEAL Analytical). Detection limits of this instrument were defined as 3 times the standard deviation of the 
blank, which corresponds to $30,7,80$, and $40 \mathrm{nM}$ for $\mathrm{NO}_{3}^{-}$, $\mathrm{NO}_{2}^{-}, \mathrm{NH}_{4}^{+}$, and $\mathrm{PO}_{4}^{3-}$, respectively. Note that the $\mathrm{NH}_{4}^{+}$concentrations were determined only for the leached solution of AM dust. We followed the method proposed by Hsu et al. (2010) to determine the concentrations of soluble trace metals leached from AM dust using an ICP-MS. The recovery yield, accuracy, and detection limit are summarized in Table S2.

\subsection{Phytoplankton identification and enumeration}

Seawater samples ( $300 \mathrm{~mL}$ volume) were collected from the baseline seawaters at each station and incubated bottles on day 4 from S1 and S2, day 3 from S3 and S5, and day 5 from S4 for the identification and enumeration of large-sized phytoplankton $(>5 \mu \mathrm{m})$. The sampling dates selected during the incubation experiment were either close to or corresponded exactly with the days that showed the maximum Chl $a$ concentrations (Fig. S1). The sampled seawater was fixed with $1 \%$ Lugol's iodine and stored in the dark until microscopic observation in the laboratory (Burson et al., 2016). Before analysis, the preserved samples were settled for $48 \mathrm{~h}$ in the dark and then concentrated to $10 \mathrm{~mL}$ volume in glass cylinders. Large-sized phytoplankton were identified and enumerated using a Nikon ECLIPSE TE2000-U inverted microscope. To illustrate the responses of different phytoplankton to various additions, the detected phytoplankton species were divided into two major functional groups: diatoms and dinoflagellates. The dominant species of diatoms found in this study were Nitzschia spp., Chaetoceros spp., Thalassiosira spp., Skeletonema spp., Cylindrotheca closterium, and Rhizosolenia setigera.

\subsection{Protocol of data analysis}

In this study, Chl $a$ concentrations generally showed a bellshaped growth curve at all stations with the maximum concentration occurring at around $2-5$ days (Fig. S1). We focused on analysing the initial 2-5 days when Chl $a$ concentration shows a steady increase during the incubation period. For example, it took 5 days to reach the maximum value of $\mathrm{Chl} a$ in the AM-dust treatment and the control at S1. In other treatments at $S 1,3$ or 4 days were required to reach the maximum value. Thus, we define the initial 5 days as a successive increase in Chl $a$ concentration at S1. The same definition is also applicable for other stations. The duration of 2-5 days for incubation has been widely used in other microcosm experiments (Herut et al., 2005; Tanaka et al., 2011; C. Guo et al., 2012; Li et al., 2015) and is expected to minimize the effects of bottle enclosure and possible deviation from the natural environment (Mackey et al., 2012; Coelho et al., 2013).

A net conversion efficiency index (NCEI) was introduced to quantify the differences in N-utilization efficiency among the AM-dust treatments and $\mathrm{N}, \mathrm{N}+\mathrm{P}$, and $\mathrm{N}+\mathrm{P}+\mathrm{Fe}$ treatments. NCEI (unit: $\mu \mathrm{gL}^{-1} / \mu \mathrm{mol} \mathrm{L}^{-1}$, i.e., $\mathrm{g} \mathrm{mol}^{-1}$ ) was calculated using the following equation:

$\mathrm{NCEI}=\frac{\sum_{i=0}^{t}\left(\mathrm{Chl} a_{\mathrm{Ti}}-\mathrm{Chl} a_{\mathrm{Ci}}\right)}{\Delta \mathrm{N}}$,

where $\mathrm{Chl} a_{\mathrm{Ti}}$ and $\mathrm{Chl} a_{\mathrm{Ci}}$ represent the Chl $a$ concentrations on the $i$ th day, i.e., day 0 , day 2 , or day $3-5$, in the treatments and the control $\left(\mu \mathrm{g} \mathrm{L}^{-1}\right)$, respectively; $\Delta \mathrm{N}$ is the decreased $\mathrm{N}$ concentration in the treatment minus that in the control during the successive increase in the incubation pe$\operatorname{riod}\left(\mu \mathrm{mol} \mathrm{L}^{-1}\right)$. The decreased $\mathrm{N}$ concentration equals the difference in $\mathrm{NO}_{3}^{-}+\mathrm{NO}_{2}^{-}$before and after the initial increase period. A large NCEI value represents a positive effect of the added $\mathrm{N}$ on phytoplankton growth, and a value close to zero represents no effect. The larger the NCEI value, the higher the N-utilization efficiency by the phytoplankton. Theoretically, the maximum increase in Chl $a$ concentration can also be used to calculate NCEI. Considering the accumulation and degradation of $\mathrm{Chl} a$, the real net conversion efficiency should be among the NCEI values between the two approaches.

We also defined the consumed ratio of $\mathrm{N}: \mathrm{P}$ (hereafter, $C_{\mathrm{N}: \mathrm{P}}$ ) and supply ratio of $\mathrm{N}: \mathrm{P}$ (hereafter, $S_{\mathrm{N}: \mathrm{P}}$ ) to illustrate the changing stocks of bioavailable $\mathrm{N}$ and $\mathrm{P}$ in various incubation experiments. $C_{\mathrm{N}}$ : P was the ratio of the difference in $\mathrm{NO}_{3}^{-}+\mathrm{NO}_{2}^{-}$concentrations at the beginning and the end of the successive increase in the incubation period to that of $\mathrm{PO}_{4}^{3-} ; S_{\mathrm{N}}$ : was the amended ratio of $\mathrm{NO}_{3}^{-}+\mathrm{NO}_{2}^{-}$to $\mathrm{PO}_{4}^{3-}$ concentrations in the incubated seawaters on day 0 in various treatments.

\section{Results}

\subsection{Characteristics of baseline surface seawater and AM dust}

Stations S1, S2, and S3 are in the open ocean and were characterized by warm surface seawaters with sea surface temperature (SST) larger than $18^{\circ}$ and a deep mixed layer with a depth larger than $80 \mathrm{~m}$. Stations S4 and S5 are in the YS and the SST and MLD therein were less than $13^{\circ}$ and $20 \mathrm{~m}$, respectively (Table 1). The winter cooling induces a lower water temperature in the shallow YS than in the deep open ocean. Therefore, the short warming time before our observations during the springtime cannot reverse this situation. The weaker winds and lesser loss of heat flux over the landsurrounding YS than over the open ocean lead to a shallower mixed depth at S4 and S5 than at S1-S3.

Low concentrations of Chl $a\left(\leq 0.50 \mu \mathrm{g} \mathrm{L}^{-1}\right)$ and nutrients $\left(\mathrm{NO}_{3}^{-}+\mathrm{NO}_{2}^{-} \leq 0.26 \mu \mathrm{mol} \mathrm{L}^{-1}, \quad \mathrm{PO}_{4}^{3-}=0.05 \mu \mathrm{mol} \mathrm{L}^{-1}\right)$ were observed at $\mathrm{S} 1$ and $\mathrm{S} 2$ in the subtropical gyre of the NWPO (Table 1), indicating oligotrophy (Hashihama et al., 2009). At S3 in the Kuroshio Extension and S4 in the YS, $\mathrm{Chl} a$ and nutrient concentrations were at least 2-fold higher 
Table 3. Nutrient and soluble trace metal contents in artificially modified and untreated dust and the theoretically increased corresponding concentrations in the incubated seawaters amended with AM dust.

\begin{tabular}{|c|c|c|c|c|c|c|c|c|c|c|c|}
\hline & \multicolumn{4}{|c|}{ Nutrients $\left(\mu \mathrm{mol} \mathrm{g}{ }^{-1}\right)$} & \multicolumn{7}{|c|}{ Soluble trace metals $\left(\mu \mathrm{gg}^{-1}\right)$} \\
\hline & $\mathrm{NO}_{3}^{-}$ & $\mathrm{NO}_{2}^{-}$ & $\mathrm{NH}_{4}^{+}$ & $\mathrm{PO}_{4}^{3-}$ & $\mathrm{Fe}$ & $\mathrm{Mn}$ & $\mathrm{Cu}$ & $\mathrm{Cd}$ & $\mathrm{Pb}$ & Co & $\mathrm{Zn}$ \\
\hline AM dust & 532.9 & 34.2 & 10.3 & 4.3 & 473.1 & 413.5 & 0.23 & 0.04 & 0.24 & 2.58 & 4.27 \\
\hline Untreated dust & 133.2 & 8.6 & 10.5 & 1.3 & 22.7 & 1.66 & $\mathrm{ND}^{\mathrm{a}}$ & ND & ND & ND & 0.03 \\
\hline $\begin{array}{l}\text { Increased concentrations } \\
\text { amended with AM dust } \\
\left(n m o l L^{-1}\right)^{b}\end{array}$ & 1066 & 68.4 & 20.6 & 8.6 & 16.90 & 15.05 & $7.2 \times 10^{-3}$ & $7.1 \times 10^{-4}$ & $2.3 \times 10^{-3}$ & 0.09 & 0.13 \\
\hline
\end{tabular}

a "ND" means no detection. ${ }^{\mathrm{b}}$ Calculated by dividing the added amounts of nutrient and soluble trace metals with AM-dust input by the incubation volume of $20 \mathrm{~L}$.

than those at S1 and S2, indicating an increased trophic state at S3 and S4. Although the nutrient levels at S5 in the YS were comparable to those at $\mathrm{S} 1$, the $\mathrm{Chl} a$ concentration of $2.74 \mu \mathrm{g} \mathrm{L}-1$ was close to the values during spring blooms in the YS (Liu et al., 2003; Fu et al., 2009; Liu et al., 2013). The $\mathrm{N}: \mathrm{P}$ ratios at $\mathrm{S} 1, \mathrm{~S} 2, \mathrm{~S} 3$, and $\mathrm{S} 5$ were far lower than the Redfield ratio $(16: 1)$, while that at $\mathrm{S} 4$ was as high as 32 (Table 1). Pico-sized Chl $a$ accounted for $>70 \%$ of the total Chl $a$ at S1 and S2, but it decreased to less than $\sim 50 \%$ at S3, S4, and S5. Specifically, large-sized phytoplankton abundance showed an increasing trend from $<20$ cells $\mathrm{mL}^{-1}$ at $\mathrm{S} 1$ and $\mathrm{S} 2$ to 35 cells $\mathrm{mL}^{-1}$ at $\mathrm{S} 4$ and 79 cells mL$^{-1}$ at $\mathrm{S} 3$, to the highest value of 314 cells $\mathrm{mL}^{-1}$ at S5. Diatoms dominated the large-sized phytoplankton community at S1, S3, and S5, and a co-dominance of dinoflagellates was noted at S2 and S4 (Table 1).

The concentration of dissolved inorganic nitrogen (DIN, i.e., $\mathrm{NO}_{3}^{-}+\mathrm{NO}_{2}^{-}+\mathrm{NH}_{4}^{+}$) in the $\mathrm{AM}$ dust was $577 \mu \mathrm{mol} \mathrm{g}{ }^{-1}$ (Table 3) and increased by a factor of 4 against that in the untreated dust. A notable increase in the $\mathrm{PO}_{4}^{3-}$ content $\left(4.3 \mu \mathrm{mol} \mathrm{g}^{-1}\right)$ in the AM dust was observed relative to the untreated dust $\left(1.3 \mu \mathrm{mol} \mathrm{g}^{-1}\right)$. The abundances of DIN, $\mathrm{PO}_{4}^{3-}$, and soluble $\mathrm{Fe}$ in the AM dust were generally consistent with the values observed in a strong dust event that occurred over the YS in the spring of 2007 (Shi et al., 2012). The $\mathrm{N}: \mathrm{P}$ ratio of $\sim 134$ in the $\mathrm{AM}$ dust was far greater than 16 (Redfield ratio) and similar to those in Asian dust aerosols previously reported (Shi et al., 2012; Liu et al., 2013; Chien et al., 2016). The $\mathrm{NO}_{3}^{-}+\mathrm{NO}_{2}^{-}$concentration in the incubated seawater after AM-dust addition increased up to $\sim 1.13 \mu \mathrm{mol} \mathrm{L}^{-1}$ (Table 3 and Fig. 2), which is larger than the baseline $\mathrm{NO}_{3}^{-}+\mathrm{NO}_{2}^{-}$stocks at $\mathrm{S} 1, \mathrm{~S} 2, \mathrm{~S} 3$, and $\mathrm{S} 5$, but accounted only for approximately one-third of the baseline stock at $\mathrm{S} 4$ (Table 1). However, the increase in $\mathrm{PO}_{4}^{3-}$ $\left(\sim 8.6 \mathrm{nmol} \mathrm{L}^{-1}\right)$ following AM-dust additions was negligible compared with the baseline P stock at each station (Tables 1 and 3).

\subsection{Variation in nutrient and total $\mathrm{Chl} a$ concentrations during incubation experiments}

During the successive increase in the incubation period (initial 2-5 days of the incubations; Sect. 2.6), $\mathrm{NO}_{3}^{-}+\mathrm{NO}_{2}^{-}$and $\mathrm{PO}_{4}^{3-}$ concentrations generally showed a decline in the control and all treatments (Fig. 2). At each station, the most obvious decline in $\mathrm{NO}_{3}^{-}+\mathrm{NO}_{2}^{-}$and $\mathrm{PO}_{4}^{3-}$ concentrations in various treatments occurred when $\mathrm{N}+\mathrm{P}$ or $\mathrm{N}+\mathrm{P}+\mathrm{Fe}$ was added. The net declines were $1.49-4.66 \mu \mathrm{mol} \mathrm{L}^{-1}$ for $\mathrm{NO}_{3}^{-}+\mathrm{NO}_{2}^{-}$and $0.18-0.27 \mu \mathrm{mol} \mathrm{L}-1$ for $\mathrm{PO}_{4}^{3-}$. The decline was $0.49-2.99 \mu \mathrm{mol} \mathrm{L}^{-1}$ for $\mathrm{NO}_{3}^{-}+\mathrm{NO}_{2}^{-}$and 0.10 $0.27 \mu \mathrm{mol} \mathrm{L}^{-1}$ for $\mathrm{PO}_{4}^{3-}$ followed by $\mathrm{N}$ and $\mathrm{P}$ additions, respectively. For $\mathrm{P}$ addition alone at $\mathrm{S} 4$, the decline in $\mathrm{PO}_{4}^{3-}$ was comparable to those in combined nutrient additions $\left(0.27 \mu \mathrm{mol} \mathrm{L}^{-1}\right)$ and that of $\mathrm{NO}_{3}^{-}+\mathrm{NO}_{2}^{-}(2.99 \mu \mathrm{mol} \mathrm{L}-1)$ was 1.3-fold larger relative to the control. Correspondingly, the addition of $\mathrm{N}+\mathrm{P}+\mathrm{Fe}$ induced the largest increases in total Chl $a$ (hereafter, $\mathrm{Chl} a$ ) among all treatments, and the increases were significant against the controls $(p<0.05)$ at all stations (Fig. 3). The maximum concentrations of $\mathrm{Chl} a$ in the $\mathrm{N}+\mathrm{P}+\mathrm{Fe}$ treatments reached $1.70 \mu \mathrm{g} \mathrm{L}^{-1}$ at $\mathrm{S} 1$ (day 4), $1.65 \mu \mathrm{g} \mathrm{L}^{-1}$ at $\mathrm{S} 2$ (day 5), $3.50 \mu \mathrm{g} \mathrm{L}-1$ at $\mathrm{S} 3$ (day 3), $4.98 \mu \mathrm{g} \mathrm{L}^{-1}$ at $\mathrm{S} 4$ (day 4), and $5.08 \mu \mathrm{g} \mathrm{L}^{-1}$ at $\mathrm{S} 5$ (day 2). This was a 1.9- to 7.1-fold increase compared to the baseline and was 1.5- to 3.0-fold larger than the controls in the five incubation experiments. The time series of Chl $a$ in $\mathrm{N}+\mathrm{P}$ and $\mathrm{N}+\mathrm{P}+\mathrm{Fe}$ treatments almost overlapped at all stations except $\mathrm{S} 2$, where the maximum value of $\mathrm{Chl} a$ in the $\mathrm{N}+\mathrm{P}$ treatment $(1.15 \mu \mathrm{g} \mathrm{L}-1)$ was only $70 \%$ of that in the $\mathrm{N}+\mathrm{P}+\mathrm{Fe}$ treatment. Significant increases in Chl $a$ relative to the control were also observed in $\mathrm{N}$ treatments at $\mathrm{S} 1$, $\mathrm{S} 2, \mathrm{~S} 3$, and S5 and in P treatments at S2 and S4 $(p<0.05)$. The maximum concentrations of $\mathrm{Chl} a$ in the $\mathrm{N}$ treatments at $\mathrm{S} 1\left(0.73 \mu \mathrm{g} \mathrm{L}^{-1}\right.$ on day 3$), \mathrm{S} 2\left(0.67 \mu \mathrm{g} \mathrm{L}^{-1}\right.$ on day 2$)$, S3 (2.14 $\mu \mathrm{g} \mathrm{L}^{-1}$ on day 3), and S5 (4.34 $\mu \mathrm{g} \mathrm{L}^{-1}$ on day 2) and in the P treatments at $\mathrm{S} 2\left(0.79 \mu \mathrm{g} \mathrm{L}^{-1}\right.$ on day 2$)$ and $\mathrm{S} 4$ $\left(4.46 \mu \mathrm{g} \mathrm{L}^{-1}\right.$ on day 3) showed a 1.3- to 3.1-fold increase compared to the baseline and were 1.2- to 1.6-fold larger than the controls. There was no significant increase in Chl $a$ 


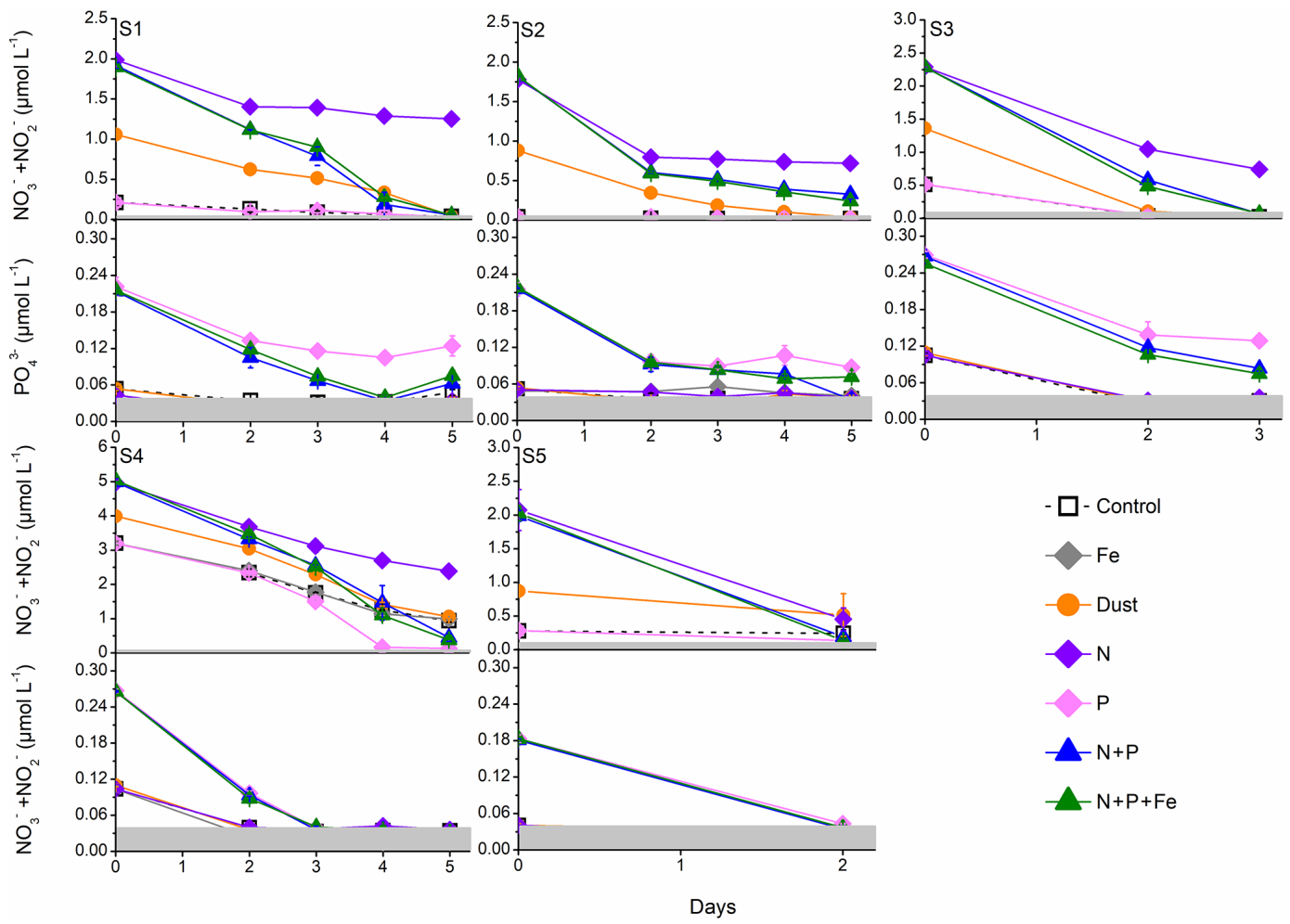

Figure 2. Changes in $\mathrm{NO}_{3}^{-}+\mathrm{NO}_{2}^{-}$and $\mathrm{PO}_{4}^{3-}$ concentrations during the successive increase in the incubation period at each station. Shaded areas indicate the values below the detection limit.

relative to the control in the rest of the additions at the five stations.

Following the addition of $\mathrm{AM}$ dust, $\mathrm{NO}_{3}^{-}+\mathrm{NO}_{2}^{-}$concentrations declined by $1.06 \mu \mathrm{mol} \mathrm{L}^{-1}$ at $\mathrm{S} 1,0.88 \mu \mathrm{mol} \mathrm{L}-1$ at $\mathrm{S} 2,1.36 \mu \mathrm{mol} \mathrm{L}^{-1}$ at $\mathrm{S} 3,2.93 \mu \mathrm{mol} \mathrm{L}^{-1}$ at $\mathrm{S} 4$, and $0.36 \mu \mathrm{mol} \mathrm{L}^{-1}$ at S5. The declines were generally larger than the values in the baseline (Fig. 2). $\mathrm{PO}_{4}^{3-}$ concentrations in AM-dust treatments declined by $0.04-0.11 \mu \mathrm{mol} \mathrm{L}^{-1}$ and were similar to those of the control during the successive increase in the incubation period at each station. Correspondingly, the maximum concentration of $\mathrm{Chl} a$ following AMdust addition was $1.04 \mu \mathrm{g} \mathrm{L}-1$ at $\mathrm{S} 1$ (day 5), $1.54 \mu \mathrm{g} \mathrm{L}^{-1}$ at S2 (day 5), $2.23 \mu \mathrm{gL}^{-1}$ at $\mathrm{S} 3$ (day 2), $3.27 \mu \mathrm{g} \mathrm{L}^{-1}$ at $\mathrm{S} 4$ (day 5), and $3.13 \mu \mathrm{g} \mathrm{L}^{-1}$ at $\mathrm{S} 5$ (day 2; Fig. 3), which was 1.1- to 4.4-fold larger against the baseline. The increases in Chl $a$ were significantly different $(p<0.05)$ from the control at S1, S2, S3, and S5. The maximum Chl $a$ concentration following AM-dust addition was 1.7-fold, 2.8-fold, and 1.3-fold larger than those in the controls at S1, S2, and S3, respectively. At $\mathrm{S} 4$ and $\mathrm{S} 5$, the maximum $\mathrm{Chl} a$ concentration in the AM-dust treatments was comparable to those in the controls. However, the $\mathrm{Chl} a$ concentrations remained relatively high in the AM-dust treatments, while showing a decreasing trend in the controls (Fig. 3).

\subsection{Variation in the size-fractionated $\mathrm{Chl} a$ concentrations during incubation experiments}

When the size-fractionated Chl $a$ was examined in various treatments at the five stations, a few notable changes were observed, as highlighted below.

a. In the controls, the dominant contributors to the total $\mathrm{Chl} a$ were pico-sized cells at S1, S2, and S4 and nanosized cells at S5, while they changed from pico-sized to micro-sized cells at $\mathrm{S} 3$ during the successive increase in the incubation period (Fig. 4). The addition of AM dust increased the $\mathrm{Chl} a$ concentrations of all sizes and the dominant contributor was consistent with those in the controls at the five stations. However, the magnitude of Chl $a$ increase was the highest for micro- or nano-sized cells following AM-dust additions. For example, the largest increase in maximum Chl $a$ occurred in micro-sized cells at S1 (2.0-fold), S2 (4.4-fold), S4 (1.4-fold), and S5 (1.6-fold) and in nano-sized cells at S3 (1-3 fold) compared with the controls.

b. Size-fractionated $\mathrm{Chl} a$ in $\mathrm{N}+\mathrm{P}$ and $\mathrm{N}+\mathrm{P}+\mathrm{Fe}$ additions showed the largest and most similar increases at S1, S3, S4, and S5, especially in the micro-sized range, in which the maximum $\mathrm{Chl} a$ concentrations showed a 1.2- to 6.5-fold increase against the controls (Fig. 4). For station S2, the micro- and nano- sized Chl $a$ showed 


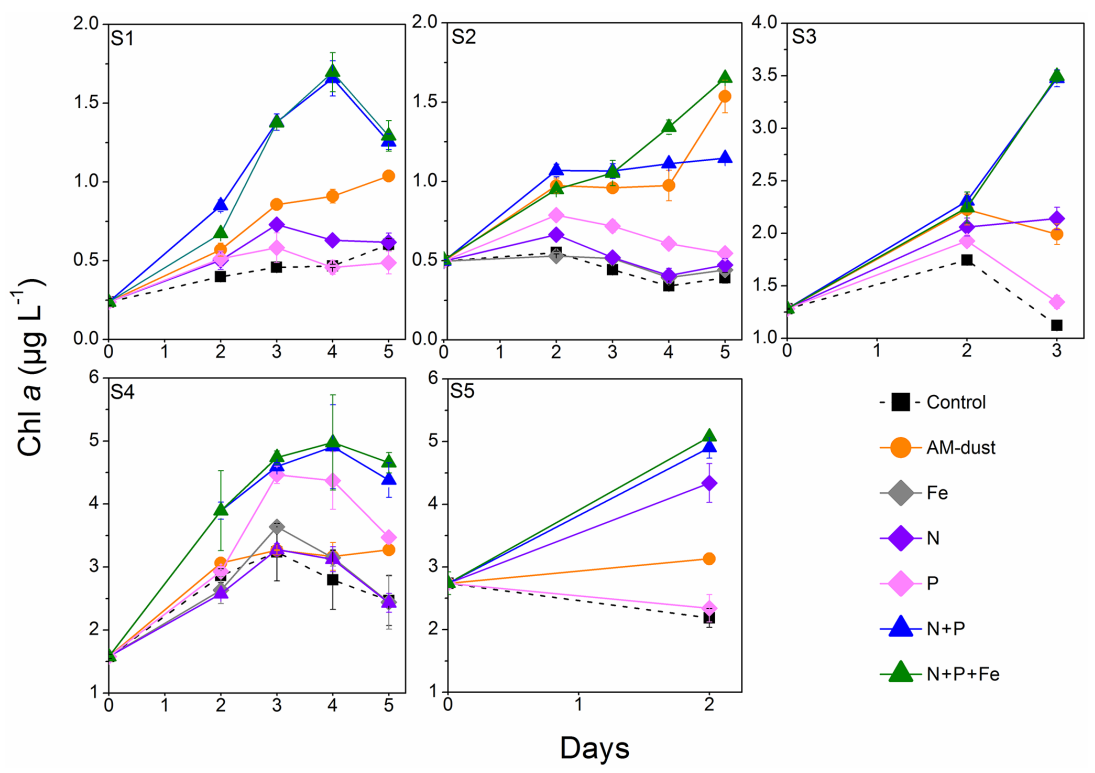

Figure 3. Changes in $\mathrm{Chl} a$ during the successive increase in the incubation period at each station.

higher increases in $\mathrm{N}+\mathrm{P}+\mathrm{Fe}$ treatments than in $\mathrm{N}+\mathrm{P}$ treatments, whereas the opposite was true for the picosized $\mathrm{Chl} a$. The addition of $\mathrm{N}$ or $\mathrm{P}$ alone also led to an increase in size-fractionated $\mathrm{Chl} a$ to some extent at all stations. The size-fractionated $\mathrm{Chl} a$ in $\mathrm{N}$ treatments at S1, S3, and S5 increased noticeably; for example, the maximum Chl $a$ showed the largest increase in nano-sized cells by a factor of 1.6 at S1 and 1.4 at S3 and in micro-sized cells by a factor of 2.2 at S5 relative to the controls. A clear increase was also observed in the P treatment at S2 and S4; for example, the maximum Chl $a$ concentrations showed a 1.8-fold (nano) and 1.5-fold (micro) increase against the controls (Fig. 4). There was no noticeable increase in any of the sizefractionated $\mathrm{Chl} a$ following $\mathrm{Fe}$ addition at $\mathrm{S} 2$ and $\mathrm{S} 4$.

c. The results of size-fractionated Chl $a$ demonstrated that the micro- and nano-sized phytoplankton generally showed a stronger response than pico-sized cells following AM-dust and various nutrient additions, although the extent of increase varied among the stations.

\subsection{Variation in large-sized phytoplankton abundance and community during incubation experiments}

After 2-5 incubation days, diatoms generally dominated the large-sized phytoplankton community in all treatments at the five stations. Chaetoceros spp. and Nitzschia spp. comprised the largest fraction of diatoms in all treatments at S1, S2, and S3. For stations S4 and S5, the dominant species of diatoms did not change compared with those in the baseline seawaters (Fig. 5). Specifically, the cell abundance of large-sized

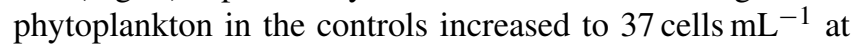

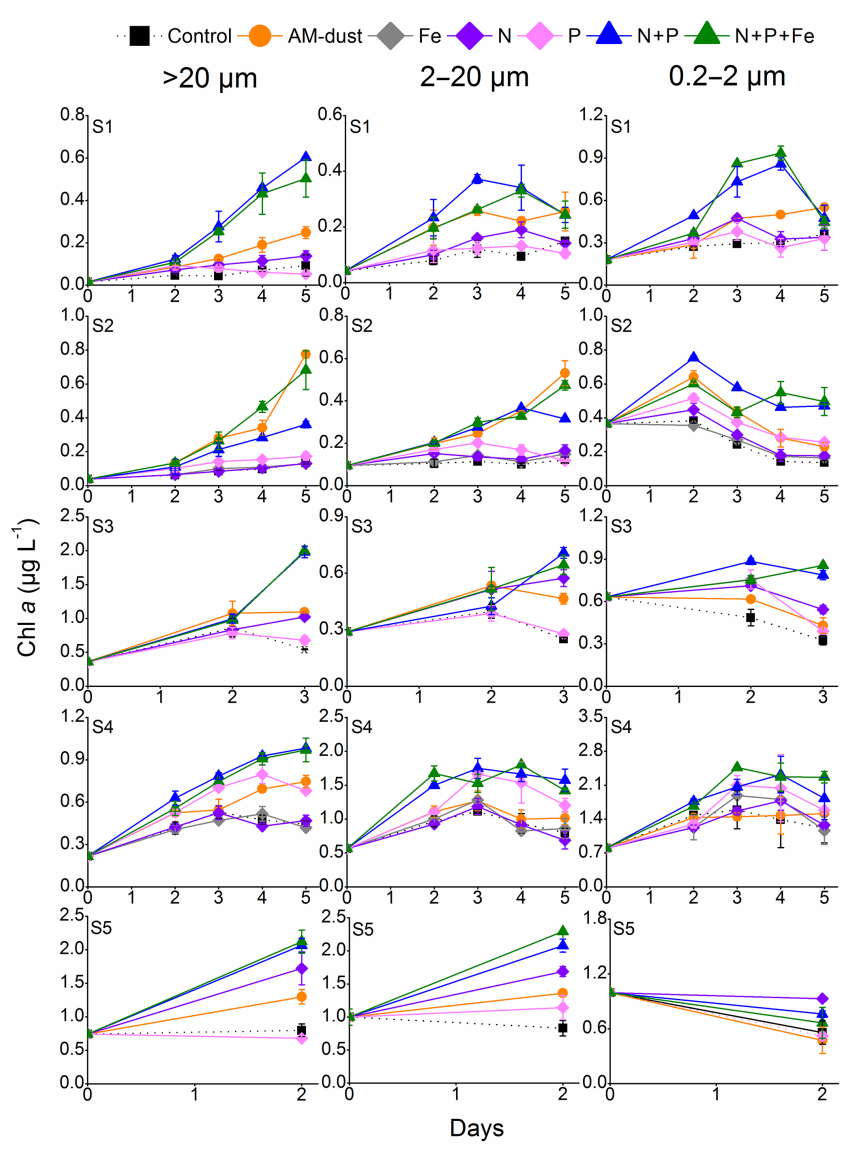

Figure 4. Changes in size-fractionated $\mathrm{Chl} a$ during the successive increase in the incubation period at each station. 

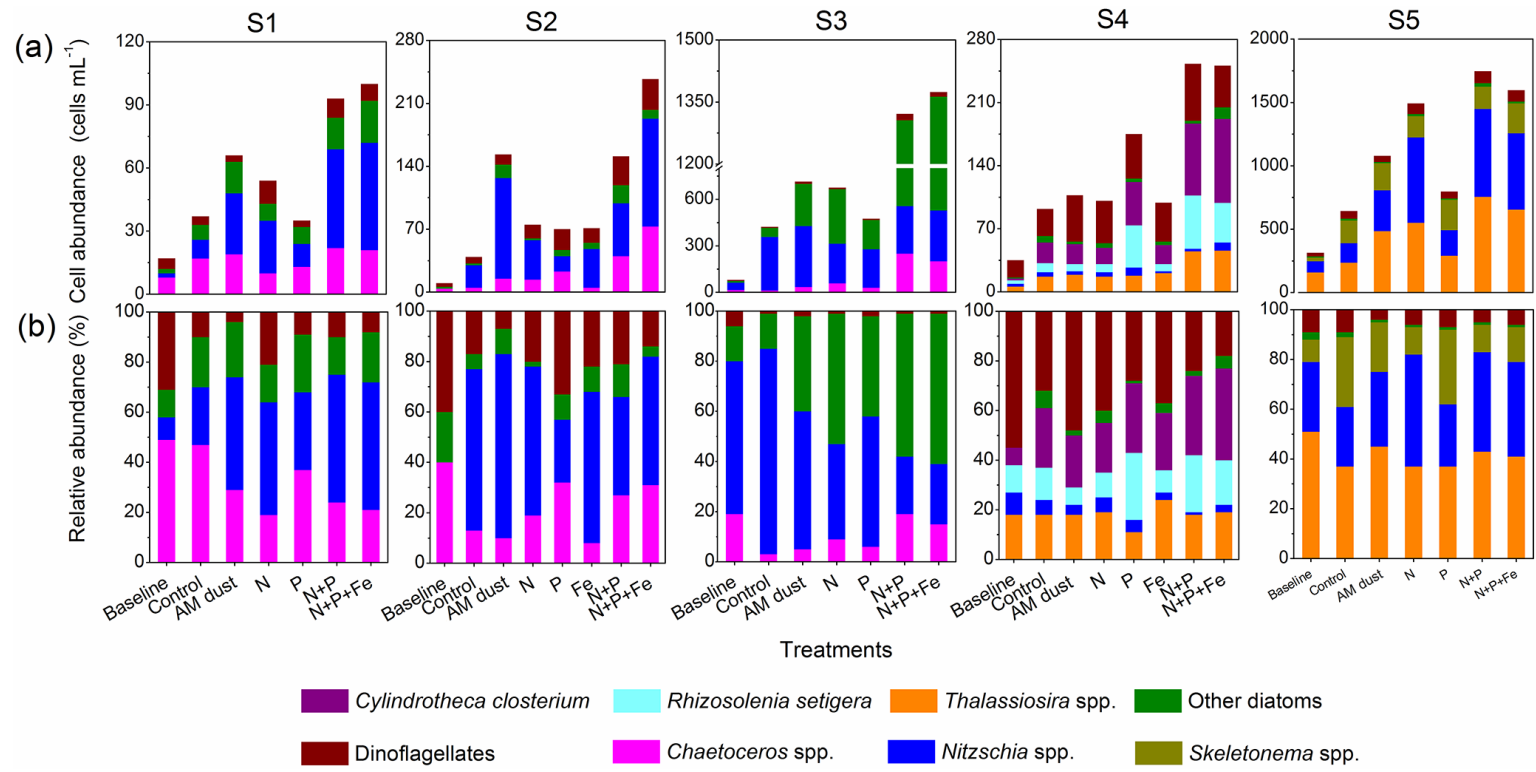

Figure 5. Changes in the taxonomic structure of a large-sized phytoplankton community before (i.e., baseline) and during (i.e., control and various treatments) the successive increase in the incubation period at each station. (a) Cell abundance of large-sized phytoplankton. (b) Relative abundance; i.e., the contribution of specific species to the large-sized phytoplankton community in cell abundance.

$\mathrm{S} 1,39$ cells $\mathrm{mL}^{-1}$ at $\mathrm{S} 2,422$ cells $\mathrm{mL}^{-1}$ at $\mathrm{S} 3,93$ cells $\mathrm{mL}^{-1}$ at $\mathrm{S} 4$, and 643 cells $\mathrm{mL}^{-1}$ at $\mathrm{S} 5$. Similar to the response of $\mathrm{Chl} a$, additions of $\mathrm{N}+\mathrm{P}$ and $\mathrm{N}+\mathrm{P}+\mathrm{Fe}$ increased the phytoplankton abundances noticeably in all treatments by about 2.5- to 2.7-fold at S1 and S5, 3.1- to 3.3-fold at S3, and 2.7fold at $\mathrm{S} 4$ relative to the controls. For single nutrient treatments, $\mathrm{N}$ additions at $\mathrm{S} 1, \mathrm{~S} 3$, and $\mathrm{S} 5$ and $\mathrm{P}$ additions at $\mathrm{S} 4$ induced the highest increases in cell abundance, with 1.5-, 1.6-, 2.3-, and 1.9-fold higher values, respectively, than those in the controls. The cell abundance of large-sized phytoplankton in AM-dust treatments relative to the controls increased by 1.8 -fold at $\mathrm{S} 1$ and 1.7 -fold at $\mathrm{S} 3$ and $\mathrm{S} 5$, but showed a negligible increase at S4. Moreover, the increases following AM-dust additions were comparable to and sometimes even larger than those in the $\mathrm{N}$ treatments at $\mathrm{S} 1, \mathrm{~S} 3$, and $\mathrm{S} 4$, but lower than the latter at S5. At S2, the cell abundance with AM-dust addition increased by 3.9-fold against the controls, which was comparable to those in the $\mathrm{N}+\mathrm{P}$ treatments (Fig. 5).

\section{Discussion}

\subsection{Nutrient limitation in the NWPO and YS}

Building on the results mentioned above (Fig. 3 and Table 1), we summarized the nutrient-limiting status at the five stations. At S1, phytoplankton growth was very likely colimited by $\mathrm{N}$ and $\mathrm{P}$ because (1) $\mathrm{N}$ addition induced a significant increase in Chl $a$ against the controls $(p<0.05)$, (2) there were significant increases in Chl $a$ following $\mathrm{N}+\mathrm{P}$ additions compared with the $\mathrm{N}$ treatments $(p<0.05)$, and (3) there were no significant differences in Chl $a$ between $\mathrm{N}+\mathrm{P}$ and $\mathrm{N}+\mathrm{P}+\mathrm{Fe}$ treatments $(p>0.05)$. At $\mathrm{S} 2$, a significant increase in Chl $a$ was observed in the $\mathrm{P}, \mathrm{N}+\mathrm{P}$, and $\mathrm{N}+\mathrm{P}+\mathrm{Fe}$ treatments $(p<0.05)$ against the controls, and the addition of $\mathrm{N}+\mathrm{P}$ and $\mathrm{N}+\mathrm{P}+\mathrm{Fe}$ induced a significantly larger response relative to the $\mathrm{P}$ treatments $(p<0.05)$. $\mathrm{Chl} a$ concentrations in the $\mathrm{N}+\mathrm{P}+\mathrm{Fe}$ treatments were significantly larger than in the $\mathrm{N}+\mathrm{P}$ treatments on days 4 5. Therefore, we concluded that phytoplankton at $\mathrm{S} 2$ were primarily co-limited by $\mathrm{N}, \mathrm{P}$, and Fe (Fig. 3). At S3, N addition induced a significant increase in Chl $a$ compared with the controls, while an even larger significant increase was observed upon $\mathrm{N}+\mathrm{P}(+\mathrm{Fe})$ addition relative to the $\mathrm{N}$ treatments. Thus, phytoplankton were primarily co-limited by $\mathrm{N}$ and $\mathrm{P}$ at $\mathrm{S} 3$. Accordingly, $\mathrm{NO}_{3}^{-}+\mathrm{NO}_{2}^{-}$and $\mathrm{PO}_{4}^{3-}$ concentrations in $\mathrm{N}+\mathrm{P}(+\mathrm{Fe})$ treatments at the three stations decreased by $73-100 \%$, which is larger than the decline in $\mathrm{NO}_{3}^{-}+\mathrm{NO}_{2}^{-}$concentrations after adding $\mathrm{N}$ alone and $\mathrm{PO}_{4}^{3-}$ concentrations after adding $\mathrm{P}$ alone (43-70\%; Fig. 2). Such co-limiting conditions have been widely reported in the oceans, especially in oligotrophic regions such as the eastern Mediterranean Sea (Tanaka et al., 2011) and the South China Sea (C. Guo et al., 2012). Moore et al. (2013) argued that low abundances of $\mathrm{N}$ and $\mathrm{P}$ in oligotrophic environments are likely to simultaneously reach the limiting levels for phytoplankton growth. Note that phytoplankton at S3 in the Kuroshio Extension showed a greater response to $\mathrm{N}$ than $\mathrm{P}$ addition. The intrusion of Kuroshio-Oyashio transition water from the north and Kuroshio water from the southwest, 
both carrying macronutrients typically with $\mathrm{N}$ : $\mathrm{P}<16$, likely changed the nutrient stocks of the seawaters at $S 3$ (Whitney, 2011; X. Guo et al., 2012; Yatsu et al., 2013). A low primary productivity in the Kuroshio Extension region during the springtime was also indicated by the low availability of nitrate in the seawater (Nishibe et al., 2015).

Similarly, we also found that $\mathrm{P}$ and $\mathrm{N}$ were the primary limiting nutrients at S4 and S5, respectively (Fig. 3). This is consistent with the baseline $\mathrm{N}: \mathrm{P}$ ratios at $\mathrm{S} 4(>16)$ and $\mathrm{S} 5$ $\left(<16\right.$; Table 1). In fact, the $\mathrm{PO}_{4}^{3-}$ after adding $\mathrm{P}$ alone at $\mathrm{S} 4$ and $\mathrm{NO}_{3}^{-}+\mathrm{NO}_{2}^{-}$after adding $\mathrm{N}$ alone at $\mathrm{S} 5$ decreased by 80 and $100 \%$, respectively, during the successive increase in the incubation period (Fig. 2). Complex hydrographic conditions, for example various riverine inputs and atmospheric deposition, create a large spatio-temporal variation in nutrient concentrations in the YS (Liu et al., 2003). The riverine input and atmospheric deposition with a high $\mathrm{N}: \mathrm{P}(>16)$ lead to relatively P-deficient conditions, while the rapid uptake by phytoplankton characterized by a lower N : $\mathrm{P}(<16)$ during the bloom period likely accelerates the decline of $\mathrm{P}$ concentrations in the surface seawaters (Liu et al., 2003, 2013; Arrigo, 2005). In general, the $\mathrm{N}: \mathrm{P}$ ratios during the springtime in the coastal waters (near S4) are higher than 16 and lower than 16 in the central waters (near S5) of the YS (Fu et al., 2009). The primary P- or N-limiting conditions in the surface seawaters of the YS have also been widely reported in previous studies (Wang et al., 2003; Liu et al., 2013).

\subsection{Positive effects of AM dust on phytoplankton growth in the NWPO and YS}

It was clear from the data that AM-dust addition increased the Chl $a$ concentrations and large-sized phytoplankton abundance to varying extents at the five stations (Figs. 3, 4 and 5). However, the increased concentrations of nutrients (e.g., N, P, and Fe) in AM-dust additions were different from those in various nutrient additions. In this study, the NCEI was proposed to quantitatively compare the utilization of $\mathrm{N}$ for the growth of phytoplankton among treatments and infer which nutrients in the AM dust primarily supported phytoplankton growth.

$\mathrm{NO}_{3}^{-}+\mathrm{NO}_{2}^{-}$was theoretically added in the AM-dust treatments at a concentration of $1.13 \mu \mathrm{mol} \mathrm{L}^{-1}$ (Table 3). However, the increase in $\mathrm{NO}_{3}^{-}+\mathrm{NO}_{2}^{-}$concentration was only $0.59-0.85 \mu \mathrm{mol} \mathrm{L}^{-1}$ immediately after the addition and mixing steps (i.e., on day 0 ) at the five stations, which was about $52-75 \%$ of the added $\mathrm{NO}_{3}^{-}+\mathrm{NO}_{2}^{-}$. Similar trends were also observed for $\mathrm{NO}_{3}^{-}+\mathrm{NO}_{2}^{-}$and $\mathrm{PO}_{4}^{3-}$ concentrations in the nutrient treatments (Fig. 2). The time interval of adding materials to the incubation bottles and sampling seawater for nutrient measurement was 1-2 h. Microbial uptake and scavenging by the cell surface and bottle wall possibly decreased the concentrations of nutrients at $1-2 \mathrm{~h}$, leading to measured values smaller than the theoretical values. When the concentrations of $\mathrm{NO}_{3}^{-}+\mathrm{NO}_{2}^{-}$and $\mathrm{PO}_{4}^{3-}$ decreased in the seawater, those absorbed by the cell surface and bottle wall had the potential to be released into the solution again to reach equilibrium (Liu et al., 2013). Thus, the theoretically added $\mathrm{N}$ and $\mathrm{P}$, plus the baseline concentrations in the seawaters, were considered the amended concentrations on day 0 , which were used for calculating the NCEI.

The added $\mathrm{N}$ in AM-dust and N-related treatments generally stimulated phytoplankton growth to varying extents, as indicated by the large NCEI values (Fig. 6). Note that the NCEI in N treatments (hereafter $\mathrm{NCEI}_{\mathrm{N}}$ ) at $\mathrm{S} 4$ was around $0 \mathrm{~g} \mathrm{~mol}^{-1}$ because the phytoplankton were primarily limited by P. The significant difference in NCEI among various nutrient treatments can also reflect the roles played by other nutrients such as $\mathrm{P}$ and $\mathrm{Fe}$ in affecting the $\mathrm{N}$ utilization efficiency. The NCEI values in the $\mathrm{N}+\mathrm{P}+\mathrm{Fe}$ treatments were $1.6 \pm 0.1 \mathrm{~g} \mathrm{~mol}^{-1}$ at $\mathrm{S} 1,1.5 \pm 0.1 \mathrm{~g} \mathrm{~mol}^{-1}$ at $\mathrm{S} 3,2.7 \pm 0.2 \mathrm{~g} \mathrm{~mol}^{-1}$ at $\mathrm{S} 4$, and $1.4 \pm 0.1 \mathrm{~g} \mathrm{~mol}^{-1}$ at $\mathrm{S} 5$, which are comparable with those in $\mathrm{N}+\mathrm{P}$ treatments (Fig. 6). This suggested that the effect of added $\mathrm{Fe}$ on the $\mathrm{N}$-utilization efficiency was negligible at the four stations. Although the added $\mathrm{Fe}$ alone had no obvious influence on the Chl $a$ concentration at S2 (Fig. 3), the higher value of $\mathrm{NCEI}_{\mathrm{N}+\mathrm{P}+\mathrm{Fe}}\left(1.8 \pm 0.0 \mathrm{~g} \mathrm{~mol}^{-1}\right)$ than the $\mathrm{NCEI}_{\mathrm{N}+\mathrm{P}}$ $\left(1.6 \pm 0.0 \mathrm{~g} \mathrm{~mol}^{-1}\right)$ therein demonstrated that Fe likely contributed to increasing the $\mathrm{N}$-conversion efficiency during Chl $a$ generation (Twining and Baines, 2015). In addition, the values of $\mathrm{NCEI}_{\mathrm{N}+\mathrm{P}}$ and $\mathrm{NCEI}_{\mathrm{N}}+\mathrm{P}+\mathrm{Fe}$ were generally higher than those of $\mathrm{NCEI}_{\mathrm{N}}$ at S1, S2, S3, and S4 (Fig. 6), which is indicative of the fact that added $\mathrm{P}$ contributed to the increased $\mathrm{N}$-utilization efficiency at these stations. Indeed, $\mathrm{P}$ is an important part of the ribosome and can promote cell division (Arrigo, 2005), which likely increased the NCEI values to some extent. Liu et al. (2013) also reported that the excessive $\mathrm{P}$ relative to $\mathrm{N}(\mathrm{N}: \mathrm{P}<16)$ in incubated seawater could increase the biomass. There were no significant differences in the NCEI values between the various treatments at S5, demonstrating that the effects of other nutrients (i.e., $\mathrm{P}$ and $\mathrm{Fe}$ ) on $\mathrm{N}$-conversion efficiency were negligible compared with $\mathrm{N}$.

The NCEI in the AM-dust treatments was $1.3 \pm 0.1 \mathrm{~g} \mathrm{~mol}^{-1}$ at $\mathrm{S} 1$ and $1.4 \pm 0.6 \mathrm{~g} \mathrm{~mol}^{-1}$ at $\mathrm{S} 4$, which was 1.7- and 16.8-fold higher than those in the $\mathrm{N}$ treatments, respectively (Fig. 6). Considering the Plimiting conditions at both stations, we concluded that the external supply of $\mathrm{P}$ associated with the AM-dust input likely also played a role in increasing the NCEI. Moreover, the $\mathrm{NCEI}_{\mathrm{AM} \text {-dust }}$ of $2.4 \pm 0.1 \mathrm{~g} \mathrm{~mol}^{-1}$ was higher than $\mathrm{NCEI}_{\mathrm{N}}+\mathrm{P}+\mathrm{Fe}\left(1.8 \pm 0.0 \mathrm{~g} \mathrm{~mol}^{-1}\right), \mathrm{NCEI}_{\mathrm{N}}+\mathrm{P}$ $\left(1.6 \pm 0.0 \mathrm{~g} \mathrm{~mol}^{-1}\right)$, and $\mathrm{NCEI}_{\mathrm{N}}\left(0.3 \pm 0.2 \mathrm{~g} \mathrm{~mol}^{-1}\right)$ at $\mathrm{S} 2$. Apart from N, P, and Fe, AM dust also provided considerable other nutrients, for example $\mathrm{Mn}$ and Co (Table 3), which may have also contributed to the phytoplankton growth in the incubations at S2 (Coale, 1991; Jakuba et al., 2008; Saito et al., 2008; Sunda, 2012). This potential synergistic 


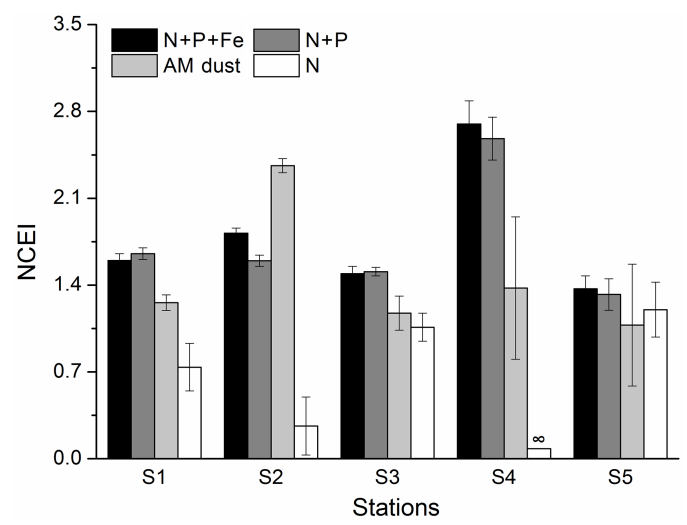

Figure 6. The net conversion efficiency index (NCEI) of N conversion to Chl $a$ in AM-dust and various nutrient additions during the successive increase in the incubation period at each station. Error bars were calculated by propagating the standard deviation of NCEI in various treatments; " $\infty$ " indicates that the standard deviation is at least threefold larger than the mean value of NCEI.

effect is worthy of further investigation. At S3 and S5, the NCEI in AM-dust treatments, i.e., $1.2 \pm 0.1 \mathrm{~g} \mathrm{~mol}^{-1}$ at S3 and $1.1 \pm 0.5 \mathrm{~g} \mathrm{~mol}^{-1}$ at $\mathrm{S} 5$, were similar to those in $\mathrm{N}$ treatments, i.e., $1.1 \pm 0.1 \mathrm{~g} \mathrm{~mol}^{-1}$ at S3 and $1.2 \pm 0.2 \mathrm{~g} \mathrm{~mol}^{-1}$ at S5 (Fig. 6), indicating a negligible effect of the dissolved $\mathrm{P}$ from AM dust on NCEI.

In recent years, more studies have challenged the use of the Redfield ratio to evaluate nutrient-limiting conditions of phytoplankton (Klausmeier et al., 2004a; Arrigo, 2005; Moore et al., 2013). Atmospheric aerosols characterized by mineral dust or anthropogenic pollutants contain complicated chemical components, and their deposition to oceans can lead to complicated responses of phytoplankton (C. Guo et al., 2012; Paytan et al., 2009; Meng et al., 2016). The NCEI appears to have the advantage of revealing the possible mechanisms associated with the responses to some extent. For instance, phytoplankton at S1, S2, and S3 were under colimiting conditions of various nutrients, while the ratios of $\mathrm{N}: \mathrm{P}$ in the seawaters were lower than a Redfield ratio of 16 (indicating $\mathrm{N}$ limitation). The difference in NCEI values among AM-dust and various nutrient treatments $(\mathrm{N}, \mathrm{P}, \mathrm{N}+\mathrm{P}$, $\mathrm{N}+\mathrm{P}+\mathrm{Fe}$ ) allows for the quantification of the role of $\mathrm{N}, \mathrm{P}$, and $\mathrm{Fe}$ in stimulating phytoplankton growth (Fig. 6). Moreover, the NCEI also reveals other nutrients which may have a promotion effect on phytoplankton at S2. Note that the calculation of NCEI was based on the change in Chl $a$ rather than biomass. In general, phytoplankton biomass increased with $\mathrm{Chl} a$, which is an essential component for photosynthesis. However, as $\mathrm{C}: \mathrm{Chl} a$ ratios could vary for different phytoplankton assemblages (Sathyendranath et al., 2009), the relationship between biomass and $\mathrm{N}$ nutrients needs to be further investigated.

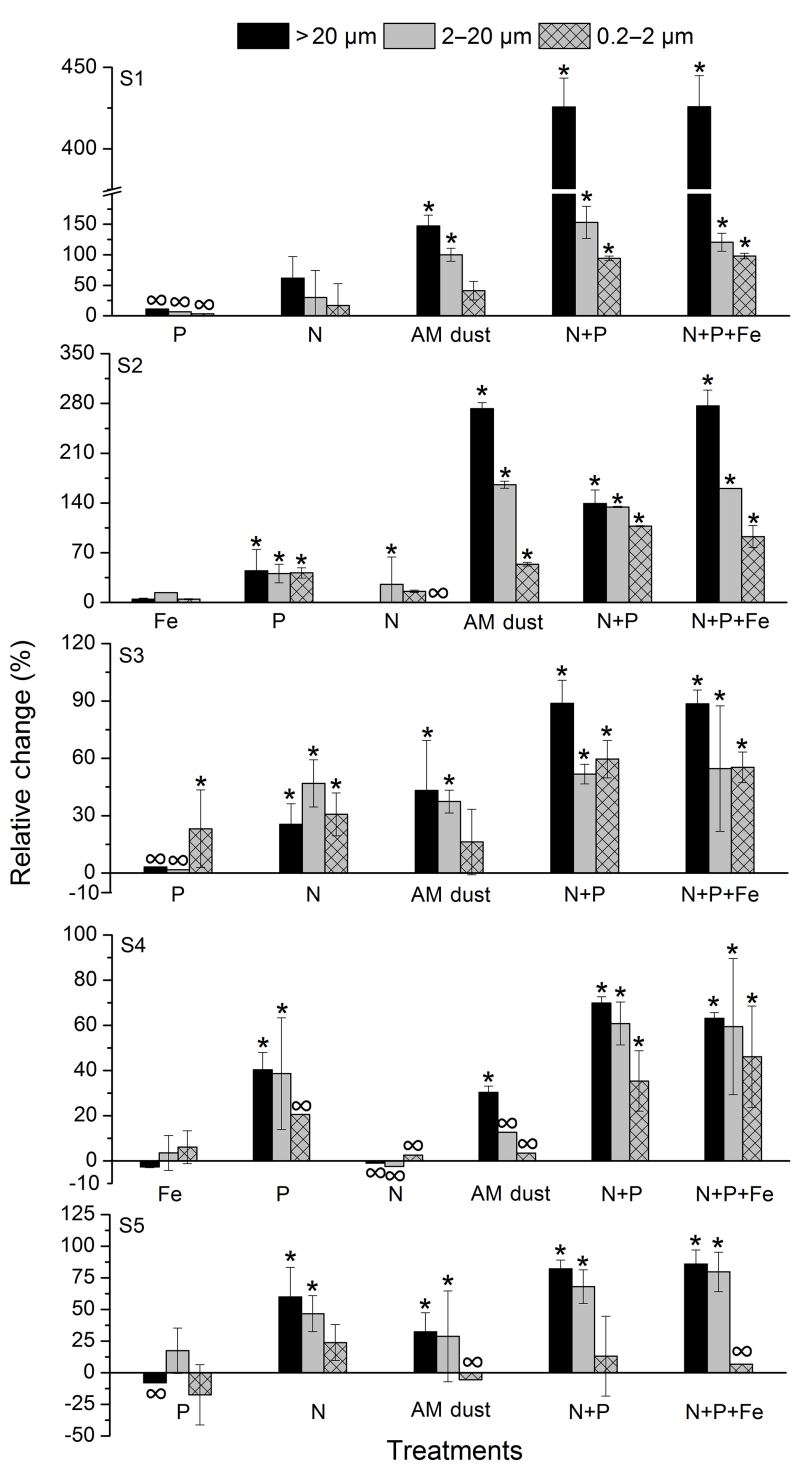

Figure 7. Relative change (\%) in size-fractionated Chl $a$ in AMdust and various nutrient treatments during the successive increase in the incubation period at each station. Relative change in this study was calculated as $100 \times($ [mean in treatments - mean in control]/mean in control). Error bars were calculated by propagating the standard deviation of mean values in the control and various treatments; " $\infty$ " indicates that the standard deviation is at least threefold larger than the mean value of relative change. Asterisks indicate that the treatment induces a significant difference in the mean of Chl $a$ compared with those in the control $(p<0.05)$.

Figure 7 shows the changes in the three size-fractionated $\mathrm{Chl} a$ concentrations in the treatments relative to the corresponding controls. Generally, the relative changes in the sizefractionated $\mathrm{Chl} a$ in AM-dust treatments showed a decreasing trend with decreasing cell size, i.e., micro-sized $\geq$ nanosized $\geq$ pico-sized cells, which is consistent with the pattern observed in $\mathrm{N}+\mathrm{P}+\mathrm{Fe}$ treatments. Previous incubation experiments have also shown that the addition of Asian 
aerosols could shift the phytoplankton size towards larger cells (C. Guo et al., 2012; Liu et al., 2013). Indeed, microand nano-sized cells, as indicated by faster uptake rates for nutrients and higher biomass-specific production rates, have a growth advantage relative to the pico-sized cells when the added materials relieve the nutrient-limiting pressures (Cermeno et al., 2005; Maranon et al., 2007, 2012). The relative changes in micro- and nano-sized $\mathrm{Chl} a$ in AM-dust treatments were generally higher than in the $\mathrm{N}$ treatments at $\mathrm{S} 1$, S2, and S4. Especially for station S2, the relative changes in micro- and nano-sized Chl $a$ in the AM-dust treatments were even larger than in the $\mathrm{N}+\mathrm{P}$ treatments and comparable to those in the $\mathrm{N}+\mathrm{P}+\mathrm{Fe}$ treatments (Fig. 7). These results demonstrated the importance of increased bioavailability of $\mathrm{P}$ at $\mathrm{S} 1$ and $\mathrm{S} 4$ and that of $\mathrm{P}$ and $\mathrm{Fe}$ at $\mathrm{S} 2$ following AM-dust addition, which supported the growth of micro- and nano-sized phytoplankton.

When the cell abundances of large-sized phytoplankton were considered, we also found that the addition of AM dust induced larger increases than $\mathrm{N}$ additions after certain incubation days at $\mathrm{S} 1$ and $\mathrm{S} 2$, as characterized by the colimitation of multiple nutrients. Especially at S2, the increase in large phytoplankton abundance was even larger than in the $\mathrm{N}+\mathrm{P}$ treatments and lower than in the $\mathrm{N}+\mathrm{P}+\mathrm{Fe}$ treatments. However, for station S3 characterized by N-P colimitation, the changes in the cell abundance of large-sized phytoplankton in AM-dust treatments were comparable to those in the $\mathrm{N}$ treatments. These results indicated that the supply of $\mathrm{N}-\mathrm{P}$ and $\mathrm{N}+\mathrm{P}+\mathrm{Fe}$ induced by AM-dust addition likely contributed to the increase in large-sized cell abundance at S1 and S2, respectively, whereas the supplied $\mathrm{N}$ from AM dust likely determined the growth of largesized phytoplankton at $\mathrm{S} 3$ because the supply of $\mathrm{P}$ from the $\mathrm{AM}$ dust was negligible relative to the baseline $\mathrm{P}$ stocks $\left(0.10 \mu \mathrm{mol} \mathrm{L}^{-1}\right)$. For station $\mathrm{S} 5$ characterized by $\mathrm{N}$ limitation alone, the addition of AM dust provided the limiting nutrient to increase the cell abundance of large-sized phytoplankton (Fig. 5).

Diatoms generally dominated the phytoplankton community in the control and treatments during the successive increase in the incubation period at S1, S2, S3, and S5 (Fig. 5). The addition of AM dust and limited nutrients induced a notable increase in the diatom cell abundance at the four stations. Indeed, when the nutrient-limitation stress was relieved, diatoms tended to prosper rapidly, which was ascribed to their fast uptake rates and quick metabolic responses to enhanced nutrient availability (Fawcett and Ward, 2011; Franz et al., 2012). The dominant species of diatoms (Chaetoceros spp., Nitzschia spp. in the open ocean and Thalassiosira spp., Skeletonema spp., Cylindrotheca closterium, Rhizosolenia setigera, and Nitzschia spp. in the YS) in this study were similar to those reported in the North Pacific and YS (Noiri et al., 2005; Aizawa et al., 2005; Sun et al., 2013). Although the dominant algae at $\mathrm{S} 4$ were diatoms in treatments that received various additions, a shift of community structure from

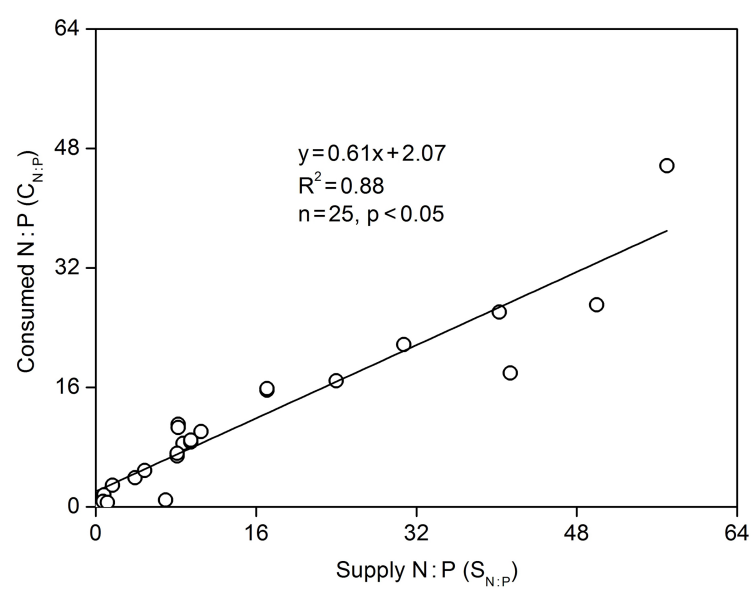

Figure 8. The relationship between the consumed $\mathrm{N}: \mathrm{P}$ ratio $\left(C_{\mathrm{N}: \mathrm{P}}\right)$ and supply $\mathrm{N}: \mathrm{P}$ ratio $\left(S_{\mathrm{N}: \mathrm{P}}\right)$ in the control and the various nutrient treatments during the successive increase in the incubation period at all stations.

diatoms to dinoflagellates was observed for AM-dust and $\mathrm{N}$ additions relative to the control. The contributions of dinoflagellates to the large-sized phytoplankton community in cell abundance reached $40-48 \%$, while there was only 18$28 \%$ among the $\mathrm{P}, \mathrm{N}+\mathrm{P}$, and $\mathrm{N}+\mathrm{P}+\mathrm{Fe}$ treatments (Fig. 5). This was closely related to the fast growth of diatoms as a result of the relief from P-limiting conditions after the addition of $\mathrm{P}, \mathrm{N}+\mathrm{P}$, and $\mathrm{N}+\mathrm{P}+\mathrm{Fe}$. It has been reported that dinoflagellates with lower demands and higher P-absorption efficiency have an advantage of surviving in P-deficient conditions compared with diatoms (Egge, 1998; Zhou et al., 2008). Hence, in contrast to P-related treatments, the supply of bioavailable $\mathrm{P}$ from AM dust was not enough to support the growth of diatoms at S4 (Fig. 5).

\subsection{Bioavailable $P$ in the AM-dust-addition experiment}

The increase in bioavailable $\mathrm{P}$ concentration following AMdust addition played an important role in stimulating phytoplankton growth at S1, S2, and S4, as mentioned above (Sect. 4.2). However, we did not detect a marked increase in the $\mathrm{PO}_{4}^{3-}$ concentrations in incubated seawaters following AM-dust additions during the successive increase in the incubation period at the three stations (Fig. 2). This could be ascribed to the gradual bioavailable $\mathrm{P}$ released over time and its rapid uptake by phytoplankton with a high $\mathrm{P}$ demand (Mackey et al., 2012) and the easy adsorption of $\mathrm{PO}_{4}^{3-}$ by particles or bottle walls (Liu et al., 2013), which likely increases $\mathrm{PO}_{4}^{3-}$ concentration in the incubated seawaters below the detection limit. In order to quantify the increased bioavailable $\mathrm{P}$ concentrations following AM-dust addition, we analysed the correlation of the $C_{\mathrm{N}: \mathrm{P}}$ and $S_{\mathrm{N} \text { : P }}$ in AMdust and $\mathrm{N}$ treatments in Fig. 8.

$C_{\mathrm{N}}$ : significantly increased with $S_{\mathrm{N}: \mathrm{P}}$ (Fig. 8 ), and the same trend was observed at each station (Fig. S2). Klaus- 


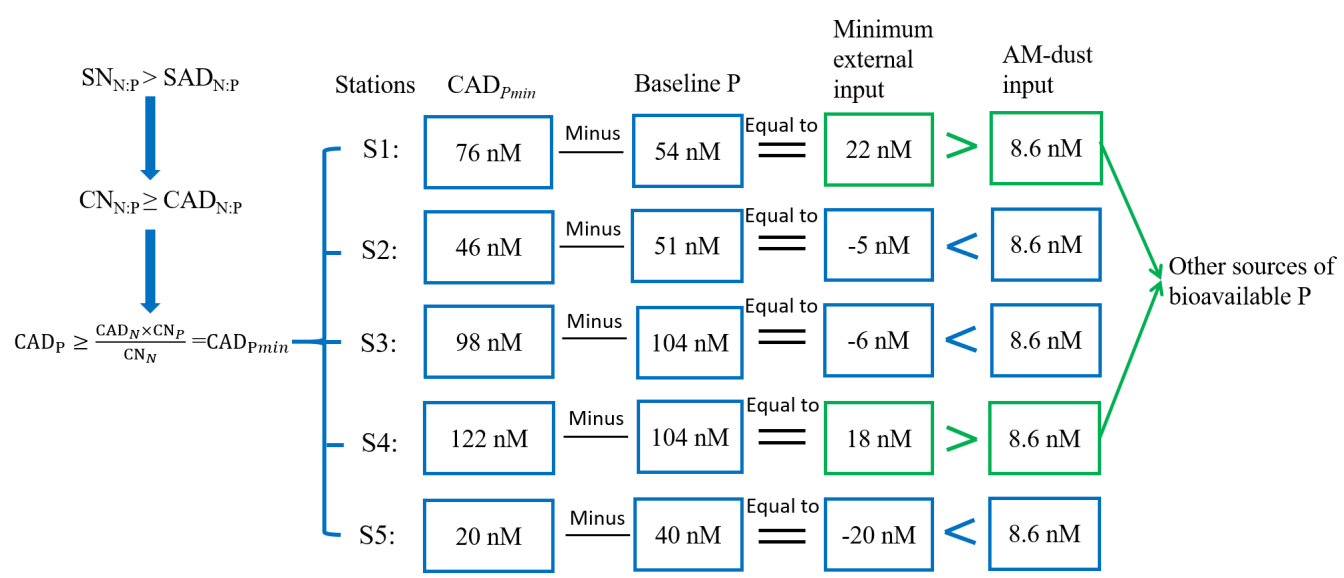

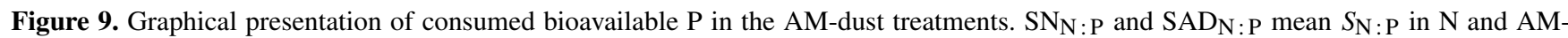
dust treatments, respectively. $\mathrm{CN}_{\mathrm{N}: \mathrm{P}}$ and $\mathrm{CAD}_{\mathrm{N}: \mathrm{P}}$ mean $C_{\mathrm{N}: \mathrm{P}}$ in $\mathrm{N}$ and $\mathrm{AM}$-dust treatments, respectively. CADPmin means the minimum consumed bioavailable $\mathrm{P}$ in the AM-dust treatments.

meier et al. (2004b, 2008) pointed out that the phytoplankton in nutrient-rich environments tend to exhibit an exponential bloomer growth with a requirement for an $\mathrm{N}$ : $\mathrm{P}$ ratio at a relatively constant value regardless of the varying nutrient supply ratios. However, when the phytoplankton tend to sustain a competitive equilibrium status in nutrient-limited environments, for example $\mathrm{N}$ or $\mathrm{P}$, their requirements for $\mathrm{N}$ : $\mathrm{P}$ ratios generally increase with the nutrient supply ratios. In our study, the phytoplankton at the five stations were limited by different nutrients and thus tended to sustain a competitive equilibrium status. As the provided DIN following the AMdust addition was $1.15 \mu \mathrm{mol} \mathrm{N} \mathrm{L}{ }^{-1}$, lower than the amount of $\mathrm{N}$ when added alone $\left(2 \mu \mathrm{molNL} \mathrm{N}^{-1}\right)$, the $S_{\mathrm{N}}$ : $\mathrm{P}$ in AM-dust treatment was lower than that in $\mathrm{N}$ treatments. Thus, $C_{\mathrm{N}}$ : $\mathrm{P}$ in both treatments at each station would follow this pattern: $C_{\mathrm{N}}$ :P in AM-dust treatments $\leq C_{\mathrm{N}}$ : $\mathrm{P}$ in $\mathrm{N}$ treatments. The consumed $\mathrm{N}$ in AM-dust treatments and $\mathrm{N}$ and $\mathrm{P}$ in $\mathrm{N}$ treatments can be determined on the basis of nutrient measurements at the beginning and the end of the successive increase in the incubation period (Fig. 2).

Because of $C_{\mathrm{N}}$ : in AM-dust treatments $\leq C_{\mathrm{N}}$ : $\mathrm{P}$ in $\mathrm{N}$ treatments, an inequality can be obtained:

$\mathrm{CAD}_{\mathrm{P}} \geq \frac{\mathrm{CAD}_{\mathrm{N}} \times \mathrm{CN}_{\mathrm{P}}}{\mathrm{CN}_{\mathrm{N}}}$

where $\mathrm{CAD}_{\mathrm{P}}\left(\mathrm{CN}_{\mathrm{P}}\right)$ and $\mathrm{CAD}_{\mathrm{N}}\left(\mathrm{CN}_{\mathrm{N}}\right)$ are the consumed bioavailable $\mathrm{P}$ and $\mathrm{NO}_{3}^{-}+\mathrm{NO}_{2}^{-}$concentrations $\left(\mu \mathrm{mol} \mathrm{L}{ }^{-1}\right)$ in the AM-dust $(\mathrm{N})$ incubation systems during the successive increase in the incubation period, respectively. "AD" and "N" mean AM-dust and $\mathrm{N}$ treatments, respectively.

The calculated result of the right term can be considered as the lower limit of the consumed $\mathrm{P}$ in the AM-dust treatments (Fig. 9). They were $76 \mathrm{nmol} \mathrm{L}^{-1}$ at S1, $46 \mathrm{nmol} \mathrm{L}^{-1}$ at $\mathrm{S} 2,98 \mathrm{nmol} \mathrm{L}^{-1}$ at S3, $122 \mathrm{nmol} \mathrm{L}^{-1}$ at S4, and $20 \mathrm{nmol} \mathrm{L}^{-1}$ at S5. Deducting the $\mathrm{P}$ concentrations in the baseline seawaters (Table 1), the minimum bioavailable $\mathrm{P}$ supplied by
AM-dust additions was estimated to be $22 \mathrm{nmol} \mathrm{L}^{-1}$ at $\mathrm{S} 1$, $-5 \mathrm{nmol} \mathrm{L}^{-1}$ at $\mathrm{S} 2,-6 \mathrm{nmol} \mathrm{L}^{-1}$ at S3, $18 \mathrm{nmol} \mathrm{L}^{-1}$ at S4, and $-20 \mathrm{nmol} \mathrm{L}^{-1}$ at S5. Note that the dissolved P from AM dust was as low as $8.6 \mathrm{nmol} \mathrm{L}^{-1}$ in the incubation bottles, which could not meet the demands of phytoplankton at $\mathrm{S} 1$ and S4. The negative values implied that the P concentrations in baseline seawaters were likely enough to support the growth of phytoplankton.

Thus, the supply other than the theoretically dissolved bioavailable $P$ of $8.6 \mathrm{nmol} \mathrm{L}^{-1}$ induced by the AM dust might exist. As reported in the literature, the dissolved organic phosphorus (DOP) is considered a significant portion of the dissolved $\mathrm{P}$ pool in oceans, especially in surface seawater (Paytan and McLaughlin, 2007). Dust input has been reported to induce the biological mineralization of DOP to DIP under P-deficient conditions and consequently increased $\mathrm{P}$ bioavailability. DIP mineralized from DOP in the seawater would even accumulate if the demand of phytoplankton for P was small (Mackey et al., 2012). Note that the gradual enhanced solubility of atmospheric $\mathrm{P}$ with the duration of exposure in seawater was also reported to contribute additional bioavailable $\mathrm{P}$ for phytoplankton growth (Ridame and Guieu, 2002; Mackey et al., 2012). However, no measurements of trace metals in seawater and DOP and P in the phytoplankton cells were made in our study. The lack of data on measurements of organic $\mathrm{P}$ makes the interpretation rather speculative but serves as a recommendation for future studies.

\section{Conclusion}

In this study, phytoplankton growth was found to be limited by two or more nutrients (i.e., $\mathrm{N}-\mathrm{P}$ or $\mathrm{N}+\mathrm{P}+\mathrm{Fe}$ ) in the NWPO and by a single nutrient (i.e., $\mathrm{N}$ or $\mathrm{P}$ ) in the YS. In the subtropical gyre of the NWPO, the addition of AM dust 
provided $\mathrm{N}-\mathrm{P}$ or $\mathrm{N}+\mathrm{P}+\mathrm{Fe}$ and micro-constituents to stimulate phytoplankton growth. In comparison with the controls, the maximum Chl $a$ following AM-dust addition showed a 1.7- and 2.8-fold increase, while the cell abundance of largesized phytoplankton showed a 1.8- and 3.9-fold increase. As the increased $\mathrm{P}$ from AM dust was negligible in comparison with the baseline $\mathrm{P}$ stocks, the dissolved $\mathrm{N}$ from $\mathrm{AM}$ dust thus primarily supported phytoplankton growth in the Kuroshio Extension. The maximum Chl $a$ concentrations and cell abundance of large-sized phytoplankton following AMdust addition were 1.3-fold and 1.7-fold larger, respectively, than those in the controls. In the YS, the increased $\mathrm{P}$ or $\mathrm{N}$ by AM-dust additions primarily contributed to the growth of phytoplankton. The Chl $a$ concentrations in AM-dust treatments were generally higher than those in the controls, although the differences in maximum Chl $a$ were negligible in both groups. The increase in the cell abundance of largesized phytoplankton was $<1$.7-fold compared with the controls. Comparing the difference in consumed $\mathrm{N}: \mathrm{P}$ between the AM-dust and $\mathrm{N}$ treatments, we found that the directly supplied bioavailable P by AM dust in the incubated seawaters was not enough to support phytoplankton growth in the YS, which is characterized by $\mathrm{P}$ limitation, and in the subtropical gyre, which is characterized by N-P co-limitation. We suggest that there are other sources of $\mathrm{P}$ during the incubation, which may be explained by the enhanced solubility of P from AM dust and/or the mineralization of DOP in the seawaters. The addition of AM dust had a potential to shift the phytoplankton towards larger cells at all incubation stations, although it did not change the dominant taxa of phytoplankton assemblages. In general, larger positive responses of phytoplankton induced by combined nutrients than by a single nutrient from the AM dust were observed in our study. This is likely related to the varying nutrient levels, community structures of phytoplankton in the baseline seawaters, and the input of nutrients following AM-dust addition.

Our study suggests the importance of an increase in bioavailable $\mathrm{P}$ stock for phytoplankton growth following AM-dust addition. This would help us better understand the effects of dust deposition on $\mathrm{P}$ cycles in the ocean. In view of the increasing anthropogenic $\mathrm{N}$ deposition in the NWPO and YS due to continuously strong $\mathrm{NO}_{x}$ emissions in eastern Asia (Kim et al., 2011, 2014), the increase in bioavailable P stock induced by dust deposition might be even more important in phytoplankton growth in the future. Moreover, further investigations are needed to better understand the differential effects of an increase in bioavailable $\mathrm{P}$ stock as a result of the atmospheric deposition on phytoplankton growth in the coastal seas and open oceans. In terms of autotrophs, the stimulation of large-sized phytoplankton growth due to the input of AM dust might enhance the carbon storage in the deep ocean, as the sinking rates of large-sized cells in the water column are higher than the pico-sized ones (Bach et al., 2012). On the other hand, the increasing anthropogenic activities in recent years can also increase the contents of heavy metal in the dust, which may inhibit phytoplankton growth (Miao et al., 2005; Paytan et al., 2009). However, the toxic effect of dust aerosol was not well reflected in our study. Therefore, further studies are also needed to illustrate the double function of dust deposition to the marine ecosystems.

Data availability. The data used in this study are available upon request to the corresponding author.

\section{The Supplement related to this article is available online at https://doi.org/10.5194/bg-15-749-2018-supplement.}

Competing interests. The authors declare that they have no conflict of interest.

Acknowledgements. This work was funded by the National Natural Science Foundation of China (NSFC; 41210008: Huiwang Gao), the Major State Basic Research Development Program of China (973 Program; 2014CB953701: Huiwang Gao), and an NSFC and Royal Society travel grant (4141101141: Huiwang Gao and Zongbo Shi).

Edited by: Manmohan Sarin

Reviewed by: four anonymous referees

\section{References}

Arrigo, K. R.: Marine microorganisms and global nutrient cycles, Nature, 437, 349-355, https://doi.org/10.1038/nature04158, 2005.

Aizawa, C., Tanimoto, M., and Jordan, R. W: Living diatom assemblages from North Pacific and Bering Sea surface waters during summer 1999, Deep-Sea Res. Pt. II, 52, 2186-2205, https://doi.org/10.1016/j.dsr2.2005.08.008, 2005.

Bach, L. T., Riebesell, U., Sett, S., Febiri, S., Rzepka, P., and Schulz, K. G.: An approach for particle sinking velocity measurements in the 3-400 $\mu \mathrm{m}$ size range and considerations on the effect of temperature on sinking rates, Mar. Biol., 159, 18531864, https://doi.org/10.1007/s00227-012-1945-2, 2012.

Baker, A., Kelly, S., Biswas, K., Witt, M., and Jickells, T.: Atmospheric deposition of nutrients to the Atlantic Ocean, Geophys. Res. Lett., 30, 2296, https://doi.org/10.1029/2003GL018518, 2003.

Boyd, P. W., Jickells, T., Law, C., Blain, S., Boyle, E., Buesseler, K., Coale, K., Cullen, J., De Baar, H., and Follows, M.: Mesoscale iron enrichment experiments 19932005: Synthesis and future directions, Science, 315, 612-617, https://doi.org/10.1126/science.1131669, 2007.

Brown, M. T., Landing, W. M., and Measures, C. I.: Dissolved and particulate $\mathrm{Fe}$ in the western and central North Pacific: Results 
from the 2002 IOC cruise, Geochem. Geophy. Geosy., 61, 1-20, https://doi.org/10.1029/2004GC000893, 2005.

Burson, A., Stomp, M., Akil, L., Brussaard, C. P., and Huisman, J.: Unbalanced reduction of nutrient loads has created an offshore gradient from phosphorus to nitrogen limitation in the North Sea, Limnol. Oceanogr., 61, 869-888, https://doi.org/10.1002/lno.10257, 2016.

Cermeno, P., Estevez-Blanco, P., Maranón, E., and Fernandez, E.: Maximum photosynthetic efficiency of size-fractionated phytoplankton assessed by ${ }^{14} \mathrm{C}$ uptake and fast repetition rate fluorometry, Limnol. Oceanogr., 50, 1438-1446, https://doi.org/10.4319/lo.2005.50.5.1438, 2005.

Chien, C. T., Mackey, K. R., Dutkiewicz, S., Mahowald, N. M., Prospero, J. M., and Paytan, A.: Effects of African dust deposition on phytoplankton in the western tropical Atlantic Ocean off Barbados, Global Biogeochem. Cy., 30, 716-734, https://doi.org/10.1002/2015GB005334, 2016.

Coale, K. H.: Effects of iron, manganese, copper, and zinc enrichments on productivity and biomass in the subarctic Pacific, Limnol. Oceanogr., 36, 1851-1864, https://doi.org/10.4319/1o.1991.36.8.1851, 1991.

Coelho, F., Santos, A., Coimbra, J., Almeida, A., Cunha, A., Cleary, D., Calado, R., and Gomes, N.: Interactive effects of global climate change and pollution on marine microbes: the way ahead, Ecol. Evol., 3, 1808-1818, https://doi.org/10.1002/ece3.565, 2013.

Duce, R., Liss, P., Merrill, J., Atlas, E., Buat-Menard, P., Hicks, B., Miller, J., Prospero, J., Arimoto, R., and Church, T.: The atmospheric input of trace species to the world ocean, Global Biogeochem. Cy., 5, 193-259, https://doi.org/10.1029/91GB01778, 1991.

Egge, J. K.: Are diatoms poor competitors at low phosphate concentrations?, J. Marine Syst., 16, 191-198, https://doi.org/10.1016/S0924-7963(97)00113-9, 1998

Franz, J., Krahmann, G., Lavik, G., Grasse, P., Dittmar, T., and Riebesell, U.: Dynamics and stoichiometry of nutrients and phytoplankton in waters influenced by the oxygen minimum zone in the eastern tropical Pacific, Deep-Sea Res. Pt. I, 62, 20-31, https://doi.org/10.1016/j.dsr.2011.12.004, 2012.

Fawcett, S. E. and Ward, B. B.: Phytoplankton succession and nitrogen utilization during the development of an upwelling bloom, Mar. Ecol.-Prog. Ser., 428, 13-31, https://doi.org/10.3354/meps09070, 2011.

Formenti, P., Schütz, L., Balkanski, Y., Desboeufs, K., Ebert, M., Kandler, K., Petzold, A., Scheuvens, D., Weinbruch, S., and Zhang, D.: Recent progress in understanding physical and chemical properties of African and Asian mineral dust, Atmos. Chem. Phys., 11, 8231-8256, https://doi.org/10.5194/acp11-8231-2011, 2011.

Fu, M., Wang, Z., Li, Y., Li, R., Sun, P., Wei, X., Lin, X., and Guo, J.: Phytoplankton biomass size structure and its regulation in the Southern Yellow Sea (China): Seasonal variability, Cont. Shelf Res., 29, 2178-2194, https://doi.org/10.1016/j.csr.2009.08.010, 2009.

Gao, Y., Arimoto, R., Duce, R., Lee, D., and Zhou, M.: Input of atmospheric trace elements and mineral matter to the Yellow Sea during the spring of a low-dust year, J. Geophys. Res.-Atmos., 97, 3767-3777, https://doi.org/10.1029/91JD02686, 1992.
Grasshoff, K., Kremling, K., and Ehrhardt, M.: Methods of seawater analysis, 3rd Edn., Wiley-VCH, 1999.

Guieu, C., Dulac, F., Desboeufs, K., Wagener, T., Pulido-Villena, E., Grisoni, J.-M., Louis, F., Ridame, C., Blain, S., Brunet, C., Bon Nguyen, E., Tran, S., Labiadh, M., and Dominici, J.-M.: Large clean mesocosms and simulated dust deposition: a new methodology to investigate responses of marine oligotrophic ecosystems to atmospheric inputs, Biogeosciences, 7, 27652784, https://doi.org/10.5194/bg-7-2765-2010, 2010.

Guo, C., Yu, J., Ho, T.-Y., Wang, L., Song, S., Kong, L., and Liu, H.: Dynamics of phytoplankton community structure in the South China Sea in response to the East Asian aerosol input, Biogeosciences, 9, 1519-1536, https://doi.org/10.5194/bg-9-15192012, 2012.

Guo, X., Zhu, X., Wu, Q., and Huang, D.: The Kuroshio nutrient stream and its temporal variation in the East China Sea, J. Geophys. Res.-Oceans, 117, C01026, https://doi.org/10.1029/2011JC007292, 2012.

Hashihama, F., Furuya, K., Kitajima, S., Takeda, S., Takemura, T., and Kanda, J.: Macro-scale exhaustion of surface phosphate by dinitrogen fixation in the western North Pacific, Geophys. Res Lett., 36, 3610, https://doi.org/10.1029/2008GL036866, 2009.

Herut, B., Zohary, T., Krom, M., Mantoura, R., Pitta, P., Psarra, S., Rassoulzadegan, F., Tanaka, T., and Thingstad, T.: Response of East Mediterranean surface water to Saharan dust: On-board microcosm experiment and field observations, Deep-Sea Res. Pt. II, 52, 3024-3040, https://doi.org/10.1016/j.dsr2.2005.09.003, 2005.

Herut, B., Rahav, E., Tsagaraki, T., Giannakourou, A., Tsiola, A., Psarra, S., Lagaria, A., Papageorgiou, N., Mihalopoulos, N., and Theodosi, C.: The potential impact of Saharan dust and polluted aerosols on microbial populations in the East Mediterranean Sea, an overview of a mesocosm experimental approach, Frontiers in Marine Science, 3, 226, https://doi.org/10.3389/fmars.2016.00226, 2016.

Hsu, S. C., Liu, S. C., Arimoto, R., Shiah, F. K., Gong, G. C., Huang, Y. T., Kao, S. J., Chen, J. P., Lin, F. J., and Lin, C. Y.: Effects of acidic processing, transport history, and dust and sea salt loadings on the dissolution of iron from Asian dust, J. Geophys. Res.-Atmos., 115, 1485-1490, https://doi.org/10.1029/2009JD013442, 2010.

Jakuba, R. W., Moffett, J. W., and Dyhrman, S. T.: Evidence for the linked biogeochemical cycling of zinc, cobalt, and phosphorus in the western North Atlantic Ocean, Global Biogeochem. Cy., 22, 1971-1976, https://doi.org/10.1029/2007GB003119, 2008.

Jickells, T., An, Z., Andersen, K. K., Baker, A., Bergametti, G., Brooks, N., Cao, J., Boyd, P., Duce, R., and Hunter, K.: Global iron connections between desert dust, ocean biogeochemistry, and climate, Science, 308, 67-71, https://doi.org/10.1126/science.1105959, 2005.

Kanakidou, M., Duce, R. A., Prospero, J. M., Baker, A. R., BenitezNelson, C., Dentener, F. J., Hunter, K. A., Liss, P. S., Mahowald, N., and Okin, G. S.: Atmospheric fluxes of organic N and $\mathrm{P}$ to the global ocean, Global Biogeochem. Cy., 26, GB3026, https://doi.org/10.1029/2011GB004277, 2012.

Kim, I.-N., Lee, K., Gruber, N., Karl, D. M., Bullister, J. L., Yang, S., and Kim, T.-W.: Increasing anthropogenic nitrogen in the North Pacific Ocean, Science, 346, 1102-1106, https://doi.org/10.1126/science.1258396, 2014. 
Kim, T. W., Lee, K., Najjar, R. G., Jeong, H. D., and Jeong, H. J.: Increasing $\mathrm{N}$ abundance in the northwestern Pacific Ocean due to atmospheric nitrogen deposition, Science, 334, 505-509, https://doi.org/10.1126/science.1206583, 2011.

Kitajima, S., Furuya, K., Hashihama, F., Takeda, S., and Kanda, J.: Latitudinal distribution of diazotrophs and their nitrogen fixation in the tropical and subtropical western North Pacific, Limnol. Oceanogr., 54, 537-547, https://doi.org/10.4319/lo.2009.54.2.0537, 2009.

Klausmeier, C. A., Litchman, E., Daufresne, T., and Levin, S. A.: Optimal nitrogen-to-phosphorus stoichiometry of phytoplankton, Nature, 429, 171-174, https://doi.org/10.1038/nature02454, 2004a.

Klausmeier, C. A., Litchman, E., and Levin, S. A.: Phytoplankton growth and stoichiometry under multiple nutrient limitation, Limnol. Oceanogr., 49, 1463-1470, https://doi.org/10.4319/lo.2004.49.4_part_2.1463, 2004b.

Klausmeier, C. A., Litchman, E., Daufresne, T., and Levin, S.: Phytoplankton stoichiometry, Ecol. Res., 23, 479-485, https://doi.org/10.1007/s11284-008-0470-8, 2008.

Krom, M. D., Shi, Z., Stockdale, A., Berman-Frank, I., Giannakourou, A., Herut, B., Lagaria, A., Papageorgiou, N., Pitta, P., and Psarra, S.: Response of the Eastern Mediterranean microbial ecosystem to dust and dust affected by acid processing in the atmosphere, Frontiers in Marine Science, 3, 133, https://doi.org/10.3389/fmars.2016.00133, 2016.

Li, Q., Legendre, L., and Jiao, N.: Phytoplankton responses to nitrogen and iron limitation in the tropical and subtropical Pacific Ocean, J. Plankton Res., 37, 306-319, https://doi.org/10.1093/plankt/fbv008, 2015.

Liu, S., Zhang, J., Chen, S. Z., Chen, H., Hong, G., Wei, H., and $\mathrm{Wu}, \mathrm{Q}$.: Inventory of nutrient compounds in the Yellow Sea, Cont. Shelf Res., 23, 1161-1174, https://doi.org/10.1016/S02784343(03)00089-X, 2003.

Liu, Y., Zhang, T., Shi, J., Gao, H., and Yao, X.: Responses of chlorophyll a to added nutrients, Asian dust, and rainwater in an oligotrophic zone of the Yellow Sea: Implications for promotion and inhibition effects in an incubation experiment, J. Geophys. Res.-Biogeo., 118, 1763-1772, https://doi.org/10.1002/2013JG002329, 2013.

Mackey, K. R., Roberts, K., Lomas, M. W., Saito, M. A., Post, A. F., and Paytan, A.: Enhanced solubility and ecological impact of atmospheric phosphorus deposition upon extended seawater exposure, Environ. Sci. Technol., 46, 10438-10446, https://doi.org/10.1021/es3007996, 2012.

Maranon, E., Cermeno, P., Rodríguez, J., Zubkov, M. V., and Harris, R. P.: Scaling of phytoplankton photosynthesis and cell size in the ocean, Limnol. Oceanogr., 52, 2190-2198, https://doi.org/10.4319/lo.2007.52.5.2190, 2007.

Maranon, E., Fernandez, A., Mourino-Carballido, B., MartinezGarcia, S., Teira, E., Cermeno, P., Choucino, P., Huete-Ortega, M., Fernandez, E., Calvo-Diaz, A., Anxelu, X., Moran, G., Bode, A., Moreno-Ostos, E., Varela, M. M., Patey, M. D., and Achterberg, E. P: Degree of oligotrophy controls the response of microbial plankton to Saharan dust, Limnol. Oceanogr., 55, 23392352, https://doi.org/10.4319/1o.2010.55.6.2339, 2010.

Maranon, E., Cermeno, P., Latasa, M., and Tadonleke, R. D.: Temperature, resources, and phytoplankton size struc- ture in the ocean, Limnol. Oceanogr., 57, 1266-1278, https://doi.org/10.4319/lo.2012.57.5.1266, 2012.

Martin, J. H.: Iron still comes from above, Nature, 353, 123-123, https://doi.org/10.1038/353123b0, 1991.

Measures, C., Cutter, G., Landing, W., and Powell, R.: Hydrographic observations during the 2002 IOC Contaminant Baseline Survey in the western Pacific Ocean, Geochem. Geophy. Geosy., 7, Q03M06, https://doi.org/10.1029/2004GC000855, 2006.

Meng, X., Chen, Y., Wang, B., Ma, Q., and Wang, F.: Responses of phytoplankton community to the input of different aerosols in the East China Sea, Geophys. Res. Lett., 43, 7081-7088, https://doi.org/10.1002/2016GL069068, 2016.

Miao, A., Wang, W., and Philippe, J.: Comparison of $\mathrm{Cd}, \mathrm{Cu}$, and $\mathrm{Zn}$ toxic effects on four marine phytoplankton by pulseamplitude-modulated fluorometry, Environ. Toxicol. Chem., 24, 2603-2611, https://doi.org/10.1897/05-009R.1, 2005.

Mills, M. M., Ridame, C., Davey, M., La Roche, J., and Geider, R. J.: Iron and phosphorus co-limit nitrogen fixation in the eastern tropical North Atlantic, Nature, 429, 292-294, https://doi.org/10.1038/nature02550, 2004.

Moore, C., Mills, M., Arrigo, K., Berman-Frank, I., Bopp, L., Boyd, P., Galbraith, E., Geider, R. J., Guieu, C., and Jaccard, S.: Processes and patterns of oceanic nutrient limitation, Nat. Geosci., 6, 701-710, https://doi.org/10.1038/NGEO1765, 2013.

Moore, C. M., Mills, M. M., Langlois, R., Milne, A., Achterberg, E. P., LaRoche, J., and Geider, R. J.: Relative influence of nitrogen and phosphorous availability on phytoplankton physiology and productivity in the oligotrophic subtropical North Atlantic Ocean, Limnol. Oceanogr., 53, 291-305, https://doi.org/10.4319/lo.2008.53.1.0291, 2008.

Noiri, Y., Kudo, I., Kiyosawa, H., Nishioka, J., and Tsuda, A.: Influence of iron and temperature on growth, nutrient utilization ratios and phytoplankton species composition in the western subarctic Pacific Ocean during the SEEDS experiment, Prog. Oceanogr., 64, 149-166, https://doi.org/10.1016/j.pocean.2005.02.006, 2005.

Nishibe, Y., Takahashi, K., Shiozaki, T., Kakehi, S., Saito, H., and Furuya, K.: Size-fractionated primary production in the Kuroshio Extension and adjacent regions in spring, J. Oceanogr., 71, 2740, https://doi.org/10.1007/s10872-014-0258-0, 2015.

Ooki, A. and Uematsu, M.: Chemical interactions between mineral dust particles and acid gases during Asian dust events, J. Geophys. Res.-Atmos., 110, 1447-1454, https://doi.org/10.1029/2004JD004737, 2005.

Paytan, A. and McLaughlin, K.: The oceanic phosphorus cycle, Chem. Rev., 107, 563-576, https://doi.org/10.1021/cr0503613, 2007.

Paytan, A., Mackey, K. R., Chen, Y., Lima, I. D., Doney, S. C., Mahowald, N., Labiosa, R., and Post, A. F.: Toxicity of atmospheric aerosols on marine phytoplankton, P. Natl. Acad. Sci. USA, 106, 4601-4605, https://doi.org/10.1073/pnas.0811486106, 2009.

Ridame, C. and Guieu, C.: Saharan input of phosphate to the oligotrophic water of the open western Mediterranean Sea, Limnol. Oceanogr., 47, 856-869, https://doi.org/10.4319/lo.2002.47.3.0856, 2002.

Ridame, C., Dekaezemacker, J., Guieu, C., Bonnet, S., L'Helguen, S., and Malien, F.: Contrasted Saharan dust events in LNLC environments: impact on nutrient dynamics and primary production, 
Biogeosciences, 11, 4783-4800, https://doi.org/10.5194/bg-114783-2014, 2014.

Saito, M. A., Goepfert, T. J., and Ritt, J. T.: Some thoughts on the concept of colimitation: three definitions and the importance of bioavailability, Limnol. Oceanogr., 53, 276-290, https://doi.org/10.4319/lo.2008.53.1.0276, 2008.

Sathyendranath, S., Stuart, V., Nair, A., Oka, K., Nakane, T., Bouman, H., Forget, M. H., Maass, H., and Platt, T.: Carbon-to-chlorophyll ratio and growth rate of phytoplankton in the sea, Mar. Ecol.-Prog. Ser., 383, 73-84, https://doi.org/10.3354/meps07998, 2009.

Shao, Y., Wyrwoll, K.-H., Chappell, A., Huang, J., Lin, Z., McTainsh, G. H., Mikami, M., Tanaka, T. Y., Wang, $\mathrm{X}$, and Yoon, S.: Dust cycle: An emerging core theme in Earth system science, Aeolian Res., 2, 181-204, https://doi.org/10.1016/j.aeolia.2011.02.001, 2011.

Shi, J., Gao, H., Zhang, J., Tan, S., Ren, J., Liu, C., Liu, Y., and Yao, X.: Examination of causative link between a spring bloom and dry/wet deposition of Asian dust in the Yellow Sea, China, J. Geophys. Res.-Atmos., 117, D17304, https://doi.org/10.1029/2012JD017983, 2012.

Shi, Z., Krom, M. D., Bonneville, S., Baker, A. R., Jickells, T. D., and Benning, L. G.: Formation of iron nanoparticles and increase in iron reactivity in mineral dust during simulated cloud processing, Environ. Sci. Technol., 43, 6592-6596, https://doi.org/10.1021/es901294g, 2009.

Strickland, J. D. H. and Parsons, T. R.: A practical handbook of seawater analysis, Fisheries Research Board of Canada, Bulletin 167, Ottawa, 1972.

Sunda, W.: Feedback interactions between trace metal nutrients and phytoplankton in the ocean, Front. Microbiol., 3, 204, https://doi.org/10.3389/fmicb.2012.00204, 2012.

Sun, J., Feng, Y., Wang, D., Song, S., Jiang, Y., Ding, C., and Wu, Y.: Bottom-up control of phytoplankton growth in spring blooms in Central Yellow Sea, China, Deep-Sea Res. Pt. II, 97, 61-71, https://doi.org/10.1016/j.dsr2.2013.05.006, 2013.
Tanaka, T., Thingstad, T., Christaki, U., Colombet, J., CornetBarthaux, V., Courties, C., Grattepanche, J.-D., Lagaria, A., Nedoma, J., and Oriol, L.: Lack of P-limitation of phytoplankton and heterotrophic prokaryotes in surface waters of three anticyclonic eddies in the stratified Mediterranean Sea, Biogeosciences, 8, 525-538, https://doi.org/10.5194/bg-8-5252011, 2011.

Twining, B. S. and Baines, S. B. The trace metal composition of marine phytoplankton, Annu. Rev. Mar. Sci., 5, 191-215, https://doi.org/10.1146/annurev-marine-121211-172322, 2013.

Wang, B. D., Wang, X. L., and Zhan, R. Nutrient conditions in the Yellow Sea and the East China Sea, Estuar. Coast. Shelf S., 58, 127-136, https://doi.org/10.1016/S0272-7714(03)000672, 2003

Whitney, F. A.: Nutrient variability in the mixed layer of the subarctic Pacific Ocean, 1987-2010, J. Oceanogr., 67, 481-492, https://doi.org/10.1007/s10872-011-0051-2, 2011.

Yatsu, A., Chiba, S., Yamanaka, Y., Ito, S.-I., Shimizu, Y., Kaeriyama, M., and Watanabe, Y.: Climate forcing and the Kuroshio/Oyashio ecosystem, ICES J. Mar. Sci., 70, 922-933, https://doi.org/10.1093/icesjms/fst084, 2013.

Zhou, M. J., Shen, Z. L., and Yu, R. C.: Responses of a coastal phytoplankton community to increased nutrient input from the Changjiang (Yangtze) River, Cont. Shelf Res., 28, 1483-1489, https://doi.org/10.1016/j.csr.2007.02.009, 2008. 